\title{
Role of Type2 Inflammatory Biomarkers in Chronic Obstructive Pulmonary Disease
}

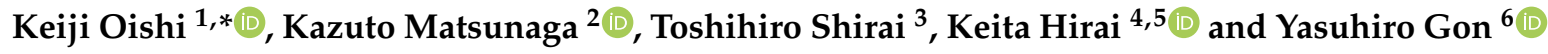 \\ 1 Department of Medicine and Clinical Science, Graduate School of Medicine, Yamaguchi University, \\ Yamaguchi 755-8505, Japan \\ 2 Department of Respiratory Medicine and Infectious Disease, Graduate School of Medicine, Yamaguchi \\ University, Yamaguchi 755-8505, Japan; kazmatsu@yamaguchi-u.ac.jp \\ 3 Department of Respiratory Medicine, Shizuoka General Hospital, Shizuoka 420-8527, Japan; \\ toshihiro-shirai@i.shizuoka-pho.jp \\ 4 Department of Clinical Pharmacology and Genetics, School of Pharmaceutical Sciences, University of \\ Shizuoka, Shizuoka 422-8526, Japan; hiraik@u-shizuoka-ken.ac.jp \\ 5 Laboratory of Clinical Pharmacogenomics, Shizuoka General Hospital, Shizuoka 420-8527, Japan \\ 6 Division of Respiratory Medicine, Department of Internal Medicine, Nihon University School of Medicine, \\ Tokyo 173-8601, Japan; gon.yasuhiro@nihon-u.ac.jp \\ * Correspondence: ohishk@yamaguchi-u.ac.jp; Tel.: +81-836-22-2248
}

Received: 17 July 2020; Accepted: 13 August 2020; Published: 18 August 2020

\begin{abstract}
Airway inflammation in chronic obstructive pulmonary disease (COPD) is typically thought to be driven by Type 1 immune responses, while Type 2 inflammation appears to be present in definite proportions in the stable state and during exacerbations. In fact, some COPD patients showed gene expression of Type2 inflammation in the airway, and this subset was associated with the inhaled corticosteroid (ICS) response. Interestingly enough, the relationship between COPD and diseases associated with Type 2 inflammation from the perspective of impaired lung development is increasingly highlighted by recent epidemiologic studies on the origin of COPD. Therefore, many researchers have shown an interest in the prevalence and the role of existent Type2 biomarkers such as sputum and blood eosinophils, exhaled nitric oxide fraction, and atopy, not only in asthma but also in COPD. Although the evidence about Type2 biomarkers in COPD is inconsistent and less robust, Type2 biomarkers have shown some potential when analyzing various clinical outcomes or therapeutic response to ICS. In this article, we review the existent and emerging Type2 biomarkers with clinically higher applicability in the management of COPD.
\end{abstract}

Keywords: airway inflammation; asthma-chronic obstructive pulmonary disease overlap; atopy; chitinase-3-like protein 1; eosinophil-derived neurotoxin; eosinophils; fractional exhaled nitric oxide; inhaled corticosteroid response; periostin

\section{Introduction}

Chronic obstructive pulmonary disease (COPD) is heterogeneous in the underlying pathophysiology of airway inflammation and its response to anti-inflammatory agents, despite being characterized by persistent respiratory symptoms and airflow limitation [1]. Although airway inflammation in COPD is typically thought to be driven by Type1 immune responses, Type2 airway inflammation appears to underlie the disease in some patients in a stable state and during exacerbations [2]. A previous study demonstrated that some COPD patients showed the gene expression of Type 2 inflammation in the airway and this subset was associated with inhaled corticosteroid (ICS) response [3]. 
Interestingly, the relationship between COPD and diseases associated with Type2 inflammation from the perspective of impaired lung development is increasingly highlighted by recent epidemiologic studies on the origin of COPD [4-12]. Given such a background, biomarkers reflecting Type2 airway inflammation may play an essential role in predicting the disease activity (i.e., predicting future exacerbations or the rate of lung function decline) and achieving medicinal precision for COPD. In fact, there has been a large number of studies about the possible role of Type 2 biomarkers in COPD in the last few years, so that the prevalence and meaning of existent Type 2 biomarkers such as sputum and blood eosinophils, exhaled nitric oxide fraction (FeNO), immunoglobulin E ( $\operatorname{IgE})$, and atopy have attracted attention in patients with COPD. Additionally, not only are Type2 biomarkers used in daily clinical practice, but emerging type 2 biomarkers are also being searched for. In this article, we discuss existent and emerging Type2 biomarkers with clinically higher applicability in the management of COPD.

\section{Type2 Airway Inflammation in COPD}

The pathogenesis of COPD is closely associated with cigarette smoking [13]. As a result, it is characterized by increased numbers of macrophages in the peripheral airway, lung parenchyma, and pulmonary vessels, together with increased activated neutrophils and increased lymphocytes that include Type $1 \mathrm{CD} 8^{+} \mathrm{T}$ (Tc1) cells, Type $1 \mathrm{~T}$ helper (Th1) cells, Type $17 \mathrm{~T}$ helper (Th17) cells, and Group 3 innate lymphoid cells (ILC3) [14]. However, in some patients, there may also be an increase in eosinophils, Type $2 \mathrm{~T}$ helper (Th2) cells, or Group 2 innate lymphoid cells (ILC2). Around $10-40 \%$ of COPD patients demonstrate increased eosinophilic inflammation in the sputum and or blood [15-17] with increased Type2-transcriptome signatures [3].

Eosinophilic airway inflammation derived from innate and adaptive immune responses is well described for asthma. Th2 lymphocytes have crucial roles in orchestrating adaptive immune responses. Allergens, presented to naïve CD4+ T cells by dendritic cells, induce differentiation toward Th2 cells, which produce interleukin (IL)-4, IL-5, and IL-13 cytokines, leading to IgE class switch in B cells, airway eosinophilia, and mucous hypersecretion [18]. On the other hand, in innate immune responses, epithelium-derived cytokines (IL-25, IL-33, thymic stromal lymphopoietin [TSLP]) are released in response to air pollutants, microbes, or glycolipids. These bind to receptors on ILC2s, activating them to produce the Th2-associated cytokines IL-5 and IL-13, which lead to eosinophilia, mucous hypersecretion, and airway hyperresponsiveness [18].

Although the mechanism of Type2 airway inflammation in COPD remains to be determined, as with Th1-mediated COPD, Type2 inflammation in COPD is likely to be a combination of innate and adaptive immunity. In particular, the role of ILC2s, which might be necessary for intrinsic asthma, but also exists in COPD, has recently been attracting attention $[19,20]$. ILC2s can be regulated by epithelial mediators released as a result of epithelial cell injury resulting from cigarette smoke and viral infection. In a mouse model of cigarette smoke-induced COPD, the expression of both IL-33 and TSLP was increased in lungs [21-24]. The upstream cytokines of TSLP are secreted from epithelial cells of COPD patients [25] and increased TSLP expression has been shown in the airway smooth muscle cells of patients with COPD [26]. IL-33 expression is also increased in epithelial progenitor cells of COPD patients and is associated with increased expression of IL-13 and the mucin 5AC gene [21]. Moreover, IL-33 in serum as well as in exhaled breath condensate was increased and correlated with the disease severity and increased blood eosinophil count in patients with COPD [27-30]. Although whether innate Type2 immune responses are involved in the pathogenesis of COPD, or whether other mechanisms are driving type 2 inflammation in COPD remains unclear, these findings suggest such involvement, especially in patients with Type2-high COPD.

As well as in the stable state, a diversity of airway inflammation is also observed in COPD exacerbations. Papi et al. evaluated the relationship among pathogens identified in COPD exacerbations and specific airway inflammation patterns [31]. They found that viral and/or bacterial infection was detected in $78 \%$ of exacerbations: viruses in $48 \%$ and bacteria in $55 \%$. Moreover, airway eosinophilia was related to exacerbations of viral infections. Other studies reported that eosinophilic airway 
inflammation was observed in $28 \%$ of exacerbations [32], and the degree of eosinophilia shown during exacerbations was higher than that seen in a stable state $[33,34]$. On the other hand, a recent study found that the blood eosinophil levels during exacerbations were lower than during a stable state [35]. This result may be explained by a report describing that the blood eosinophil counts decreased due to the influence of the bacterial load at the time of exacerbation compared with the stable state [36]. These inconsistent results may be due to the heterogeneity of airway inflammation in the COPD exacerbations.

\section{Relationship between COPD and Type2 Inflammation from the Perspective of Impaired Lung Development}

The controversy that asthma and COPD are not always separate diseases began with the Dutch Hypothesis in 1961 [37], and there has been a growing appreciation over the years. Nowadays, Asthma-COPD overlap (ACO) has been identified in clinical practice by the features that it shares with both asthma and COPD. Of note, the relationship between COPD and diseases associated with Type2 inflammation is highlighted by recent epidemiologic studies on the origin of COPD [4-12]. In the Tasmanian Longitudinal Health Study, 8583 participants were followed from 7 to 53 years of age with spirometry at $7,13,18,45,50$, and 53 years [12]. This study found that not only personal smoking but also childhood asthma, allergic rhinitis, eczema, bronchitis, pneumonia, and maternal smoking were significant risk factors for reduced pulmonary function. Moreover, if the forced expiratory volume in $1 \mathrm{~s}\left(\mathrm{FEV}_{1}\right)$ was lower than average early in life, the decline accelerated. The group had a high rate of childhood asthma (37\%), and $46 \%$ of the subjects in the group developed COPD at 53 years of age. Because childhood asthma, allergic rhinitis, and eczema are well associated with Type 2 inflammation, this study clearly suggests the involvement of Type 2 inflammation in the pathogenesis of COPD. In this context, the importance of Type2 biomarkers in COPD may increase.

\section{Existent Type2 Biomarkers in COPD}

\subsection{Sputum Eosinophils}

Sputum eosinophilia in asthmatics is strongly associated with a good response to corticosteroid therapy, and tailored strategies aimed to normalize sputum eosinophils reduce the exacerbation frequency and severity [17]. Sputum eosinophilia is occasionally seen in COPD patients in a stable state and during exacerbations [16,38-40]. Studies have used a threshold of $2 \%$ or $3 \%$ in sputum for defining eosinophilic airway inflammation in COPD $[16,32,39,41]$. Sputum eosinophilia in COPD patients in a clinically stable state predicts a risk of future exacerbations and is associated with a favorable response to ICS $[16,39,41-43]$. Moreover, a study from the SPIROMICS cohort $(n=2737)$ found that elevated sputum eosinophils had significant associations with multiple measures of COPD severity, including exacerbations, airflow limitation, and worse quality of life [44]. Although induced sputum is less invasive than tissue biopsy, it is somewhat difficult to perform and not available in every clinical setting. Furthermore, sputum induction can sometimes cause airway constriction. Due to these drawbacks, the induction of sputum eosinophils, although highly useful, is not widely used in clinical practice.

\subsection{Blood Eosinophils}

\subsubsection{Blood Eosinophil Levels in COPD and Modifying Factors}

The blood eosinophils levels have been proposed as a surrogate marker of sputum eosinophils, which has the weaknesses referred to in the previous section but is widely used for both asthma and in COPD. The blood eosinophil level in asthmatics has a well-established correlation with sputum eosinophils, and serves as a biomarker for future exacerbations, a decline in lung functions, and the response to ICS and biologics [45-50]. On the other hand, in COPD patients, the correlation between contemporaneous blood eosinophils and sputum eosinophils has been discussed, and discordances have been noticed between sputum, tissue, and blood eosinophil counts [44,51-54]. In a recent study, 
blood and sputum eosinophils in COPD patients did not correlate as well as in patients with asthma [49]. Interestingly, in elderly subjects and patients with comorbidities such as hypertension, ischemic heart disease, and atrial fibrillation, no correlation between blood and sputum eosinophils was found. Since most COPD patients have those characteristics and comorbidities, this finding is very important when considering blood eosinophils as a biomarker in clinical practice.

Although there are challenges to using blood eosinophils as a surrogate marker of sputum eosinophils, many studies have investigated the blood eosinophil levels in COPD patients because of their simplicity. The prevalence of blood eosinophilia in patients with COPD varies depending on the study population and threshold used for evaluation. In the Copenhagen General Population Study ( $n=7225$ ), $23 \%$ of patients had blood eosinophil counts $\geq 280$ cells $/ \mu L$ [55]. In a post-hoc analysis of the WISDOM trial $(n=2420), 53 \%$ of patients had $\geq 150$ eosinophil cells $/ \mu \mathrm{L}, 20 \%$ had $\geq 300$ eosinophil cells $/ \mu \mathrm{L}$, and $11 \%$ had $\geq 400$ eosinophil cells/ $\mu \mathrm{L}$ [56]. In the Hokkaido COPD cohort study, excluding asthma carefully by respiratory specialists, $19 \%$ of the patients had blood eosinophil counts $\geq 300$ cells/ $\mu \mathrm{L}$ [57].

Another critical point is that the stability and reproducibility of blood eosinophil measurements have also been debated $[16,35,58,59]$. Data on two large cohorts of COPD patients revealed that, in three measurements of blood eosinophils measured over two years, there was considerable variability in blood eosinophils, with only $15 \%$ of patients showing a persistently high blood eosinophil count (>300 cells/ $/ \mathrm{L}$ ) [59]. This is because, regardless of the airway inflammation, the blood eosinophils are affected by various factors such as drugs, malignant tumors, and parasitic infections [60], so a single measurement of blood eosinophils may not be reliable. For example, a previous study using a single measurement found that, in stable COPD patients, the optimal cut-off value for blood eosinophils, which reflects sputum eosinophils $\geq 3 \%$, was 215 cells/ $\mu \mathrm{L}$ (area under the curve [AUC] 0.76, sensitivity $60 \%$ and specificity 93\%) [61]. However, in another study, only half of the patients with blood eosinophils of 215 or greater had sputum eosinophils $\geq 3 \%$ [49]. From the aspect of influential factors, stability, and reproducibility, more systematic studies of blood eosinophils in COPD patients are needed to establish surrogate markers that reliably reflect the airway inflammation.

\subsubsection{Blood Eosinophils as a Predictor for COPD Exacerbations}

It is clear that elevated blood eosinophil counts are a risk factor for future exacerbations in patients with asthma [62]. In the field of COPD, several studies have investigated whether the blood eosinophils can be used to predict future exacerbations. The results have varied, with both negative and positive findings reported $[15,44,54,55,57,59,63-67]$. In a prospective analysis from the Copenhagen General Population Study, higher blood eosinophil levels during stable phase ( $>340$ cells $/ \mu \mathrm{L})$ were associated with a 1.76-fold increased risk of severe exacerbations [55]. A historical population study suggested that patients with elevated blood eosinophil levels $(>450$ cells $/ \mu \mathrm{L})$ had a $13 \%$ higher exacerbation rate during the following year than those with lower levels, with the findings being most clearly demonstrated in patients who were ex-smokers [66]. A recent publication showing both cross-sectional and prospective data from COPDGene and ECLIPSE described that higher blood eosinophil levels $(>300$ cells $/ \mu \mathrm{L}$ ) were associated with increased exacerbation risk, the incidence rate ratios of which were 1.32 and 1.22, respectively [15]. Especially, the findings were most clearly found in patients with a history of frequent exacerbations. These studies, which showed an association between blood eosinophils and frequency of exacerbations, should take into account the large proportion of patients with a history of frequent exacerbations.

On the other hand, several studies showed that the exacerbation rate of COPD patients was not related to blood eosinophil levels $[44,54,57,59,64,65,67]$. In these studies, there was no association even when examined with different cut-off values at a cut-off of $\geq 200$ or $\geq 300$ cells $/ \mu \mathrm{L}$, or $\geq 2 \%, \geq 3 \%$, or $\geq 4 \%$. Of note, Casanova et al. investigated the prevalence and stability of a high level of blood eosinophils ( $\geq 300$ cells $/ \mu \mathrm{L}$ ) and its relationship to future exacerbations by using the data from two large cohorts of COPD patients [59]. They found that, in three measurements of blood eosinophils measured over 
two years, there was notable variability in the levels of blood eosinophils. Blood eosinophil levels $\geq 300$ cells $/ \mu \mathrm{L}$ persisting over two years were not a predictor for COPD exacerbations. Also, data from the SPIROMICS cohort demonstrated that the blood eosinophil level as a single biomarker did not accurately predict sputum eosinophils, and did not show an association with exacerbations unless observed in the background of increased sputum eosinophils [44]. Thus, much remains to be done to utilize the blood eosinophils as a predictor of exacerbations in COPD patients.

\subsubsection{Relationship between Lung Function and Blood Eosinophils in COPD}

It is well known that the blood eosinophils are strictly related to the lung function in adult asthma, and blood eosinophils are associated with airflow obstruction and enhanced decline in lung function [68]. However, only a small number of studies have investigated the influence of blood eosinophils on the decline in lung function. The Hokkaido COPD Cohort Study Group investigators reported that patients with a rapid decline in $\mathrm{FEV}_{1}$ displayed lower levels of blood eosinophils [69,70]. Moreover, they suggested that patients with elevated blood eosinophils ( $\geq 300$ cells $/ \mu \mathrm{L})$ had significantly slower annual FEV $\mathrm{F}_{1}$ decline [57]. In contrast, the ECLIPSE investigators found no significant differences in the rate of decline in $\mathrm{FEV}_{1}$ according to the blood eosinophil pattern using a cut-off value of $2 \%$ [16]. This finding was similar to that in another study using a cut-off value of $300 \mathrm{cells} / \mu \mathrm{L}$ [67]. Although further large cohort longitudinal studies are needed, the effect of blood eosinophils on respiratory function in COPD patients may not be as strong as that in asthma patients.

\subsubsection{Blood Eosinophils as a Biomarker of ICS Treatment Response in COPD}

From the viewpoint of the effectiveness and the risk of adverse effects such as pneumonia and osteoporosis [71,72], there is a need to identify which patients will benefit from ICS. A number of studies have investigated whether the blood eosinophil levels can be used to predict the effectiveness of ICS. In particular, many studies examined whether blood eosinophil levels can be used to predict whether patients will benefit from the prevention of future exacerbations by add-on ICS therapy in combination with long-acting $\beta 2$-agonist (LABA) or LABA/long-acting muscarinic antagonist (LAMA) compared to bronchodilators alone [73-81]. Judging from these reports, the Global Initiative for Chronic Obstructive Lung Disease (GOLD) statements have recommended the use of ICS in combination with LABA or LABA/LAMA in patients with frequent exacerbations and blood eosinophil counts $\geq 300$ cells $/ \mu \mathrm{L}$, and is considering the use of ICS in combination with LABA or LABA/LAMA when blood eosinophil counts are between 100 and 300 cells/ $\mu \mathrm{L}$, while ICS is not at all recommended if the blood eosinophil counts are $<100$ cells $/ \mu \mathrm{L}$ [14].

A few studies have investigated the usefulness of blood eosinophils to predict the risk of exacerbations after ICS withdrawal from triple therapy (ICS/LABA/LAMA) [56,82]. Similar results were obtained, and only patients with baseline elevated blood eosinophil counts ( $\geq 300$ or 400 cells $/ \mu \mathrm{L}$ ) were at an increased risk of exacerbations compared with patients with lower eosinophil counts.

In contrast, several observational studies among COPD patients using ICS did not find an association between blood eosinophilia and reduced risk of exacerbations [83,84]. The lack of relationship shown in the observational studies suggests that this association may not be present within the real-world COPD population. Although randomized controlled trials (RCTs) address important findings for us, we need to keep in mind that it has been estimated that the patients with COPD selected for RCTs are representative of about $7 \%$ of the entire COPD population [85].

In a real-world survey, most COPD patients belonged to GOLD A or B, who are less likely to experience exacerbations but continue to have daily symptoms $[86,87]$. Therefore, knowledge concerning the effects of ICS other than preventing exacerbations, such as increased lung function and improvement of symptoms, are also required. A few studies have sought to determine whether the blood eosinophil levels can predict which patients will benefit in terms of lung function and/or symptoms from add-on ICS therapy. In a post-hoc analysis of the ISOLDE study, which compared an ICS with placebo, patients were also stratified using a baseline blood eosinophil threshold of $2 \%$ [75]. 
This study found that a baseline blood eosinophils $\geq 2 \%$ identified a group of patients with slower rates of decline in $\mathrm{FEV}_{1}$ when treated with ICS. Recently, we reported a prospective study to detect Type2 biomarkers for predicting short-term improvements in both quality of life (QOL) and airflow limitation by ICS in 43 symptomatic COPD patients who had been taking bronchodilators (De-stress study) [88]. The study excluded subjects who were current smokers with concomitant asthma. Seventy percent of the patients took LAMA/LABA, and 90\% of the patients were classified as GOLD B. After 12 weeks of ICS treatment, $28 \%$ of the patients showed significant improvement in the COPD assessment test (CAT) and $\mathrm{FEV}_{1}$. Among the several Type2 biomarkers, the absolute blood eosinophil counts and the percentage of blood eosinophils were less likely to predict the efficacy of ICS compared to FeNO. Nonetheless, our results did not exclude the possibility of blood eosinophils being used to predict the effects of ICS in COPD. In fact, more than $60 \%$ of patients with blood eosinophilia ( $\geq 300$ cells $/ \mu \mathrm{L}$ ) showed favorable effects from ICS in the present study. Due to the discrepancies reported in various studies, further studies are needed to determine whether blood eosinophils are useful as a biomarker for determining the use of ICS.

\section{3. $\mathrm{FeNO}$}

\subsubsection{FeNO Levels in COPD and Modifying Factors}

FeNO has been established as a useful biomarker of Type2 airway inflammation and a guide for anti-inflammatory therapy in asthma [89-91]. Currently, FeNO values can be determined noninvasively, reproducibly, and easily measured in close to real-time using portable analyzers. Therefore, the Global Initiative for Asthma recommends that FeNO should be used as part of the clinical assessment in asthma [92]. Nitric oxide is produced mainly by inducible nitric oxide synthetase (iNOS) in the epithelial cells of the bronchial wall in response to IL-4 and IL-13 via the signal transducer and activator of transcription 6 pathway [93]. Since FeNO is a surrogate biomarker for Type2-high asthma, particularly a downstream molecule of IL-4/13, several trials to apply FeNO to a biomarker to predict the efficacy of asthma drugs targeting IL-4/13 have been performed [94,95].

The role of FeNO in COPD remains controversial. Although iNOS is highly expressed in COPD patients [96-98], the results of studies of the FeNO levels in COPD are contradictory, showing elevated, similar, and reduced levels. According to a recent systematic review and metanalysis, FeNO levels varied widely among several studies $\left(\mathrm{I}^{2}=96 \%\right)$ and were mildly elevated in patients with stable COPD compared with healthy controls (standard mean difference [SMD] 1.21, 95\% confidence interval [CI] 0.47-1.96) [99]. Additionally, it was found that the FeNO levels were much higher in ex-smokers than in current smokers (SMD 2.05, 95\% CI 1.13-2.97). This heterogeneity can be explained by various factors. It is known that current smoking reduces the FeNO levels through reduced production and increased consumption of NO [100-102]. In addition, ICS treatment decreases the FeNO levels [88,103-105]. FeNO is also influenced by comorbidities such as atopy and rhinitis [101,102].

There are many studies that compared FeNO in COPD subjects with ACO [106-113]. Although higher levels of FeNO were observed in ACO patients compared to those with COPD-only, it is still difficult to interpret the results of these studies. These studies used not only different cut-off values but also different definitions of ACO. Meanwhile, Tamada et al. investigated 331 COPD patients for asthma-like airway inflammation or atopic factors using FeNO and serum IgE, respectively [112]. In this study, the values of FeNO were shown in detail, even the histogram. The prevalence rate of FeNO $>25 \mathrm{ppb}$ was $36.9 \%$, those of $>35 \mathrm{ppb},>50 \mathrm{ppb}$ were $16.3 \%$, and $5.1 \%$, respectively. Similarly, another recent study reported that, in 178 severe $\left(\mathrm{FEV}_{1}\right.$ predicted $\left.\leq 50 \%\right)$ COPD patients, $\mathrm{FeNO} \geq 25 \mathrm{ppb}$ was found in $32.9 \%$, and $\mathrm{FeNO} \geq 50 \mathrm{ppb}$ was $2.6 \%$ [113].

\subsubsection{Relationship to COPD Exacerbations in FeNO}

Several studies have addressed the relationship between COPD exacerbations and FeNO. In the changes of the FeNO levels, most studies reported that FeNO significantly increased during 
exacerbations [31,114-118]. High FeNO values in hospitalized COPD exacerbation patients returned to the control values only months after these steroid-treated patients were discharged [116]. Rhinovirus infections induce increases in the FeNO levels as a result of upregulated iNOS expression in the airway epithelium [119]. Viral infections are a major cause of COPD exacerbations [120]. Thus, the elevation of FeNO in COPD exacerbations may be the direct result of viral infection.

Fewer studies have examined whether FeNO is a predictive marker for COPD exacerbations. A recent prospective study showed that persistently elevated FeNO levels ( $\geq 20 \mathrm{ppb}$ ) in stable COPD patients were associated with a significantly higher risk of exacerbations [121]. After adjusting for potential confounding variables, the hazard ratio for exacerbations was higher in the latter group (1.579 [95\% CI 1.049-2.378], $p=0.029$ ). Moreover, the time to first moderate and then severe exacerbations was shorter in patients with persistently high FeNO.

\subsubsection{Relationship between Lung Function and FeNO in COPD}

High FeNO levels in severe asthma could be used to identify patients with the greatest airflow limitation [122]. Previous prospective studies in asthmatics showed that higher levels of FeNO were associated with a rapid decline in lung function [123]. IL-4/IL-13 pathways facilitate airway smooth muscle contraction and proliferation, and goblet cell hyperplasia, mucus production, increased extracellular matrix secretion by fibroblasts, and subepithelial basal membrane thickening, all of which are features of airway obstruction [124]. The roles of IL-4 and IL-13 in orchestrating the pathogenesis of asthma may help to explain the relationship between high FeNO levels and airflow limitation. However, the relationship between lung function and FeNO in COPD is not well understood. Most studies reported no association between the FeNO levels and pulmonary function [104,108,112,125-127], while two studies showed an association. One study found a negative correlation between $\mathrm{FEV}_{1} /$ forced vital capacity (FVC) ratio and the FeNO levels in patients with COPD ( $\mathrm{r}=-0.59, p=0.028)$ [128]. Another study showed that there was a negative correlation between the FeNO values in COPD and FEV 1 $(\mathrm{r}=-0.50, p=0.004)$ [129]. In contrast to previous findings, it has been reported that there was a higher proportion of patients with severe airflow limitation in the low FeNO group $(<25 \mathrm{ppb})$ compared with the high FeNO group [130]. This discrepancy may be derived from the patients' heterogeneity, such as age and treatment, and differences in the cut-off values of FeNO in each study.

\subsubsection{FeNO as a Biomarker of the ICS Treatment Response in COPD}

FeNO might be a predictive biomarker of the response to ICS treatment in COPD as in asthma. A recent systematic review and meta-analysis investigated the response of the FeNO levels to ICS treatment in COPD patients [131]. Five studies of 171 patients were included in the analysis. Two-thirds were ex-smokers, and this analysis excluded studies with patients having a diagnosis of asthma. There was a significant decrease of FeNO in ex-smoking COPD patients following ICS treatment (-7.51, $95 \%$ CI: -11.51 to $-3.51 ; p=0.003)$, and in a population of subjects that included both smokers and ex-smokers. However, this analysis focused on the changes of FeNO as a treatment response so it was not possible to analyze the association of FeNO levels with QOL, pulmonary function, or reduction in exacerbations. Some studies found an inverse relationship between FeNO levels and $\mathrm{FEV}_{1}$ in ex-smokers but not in smokers with COPD [115,132,133].

Several studies demonstrated that FeNO predicted the response when adding corticosteroids. Elevated FeNO in COPD patients may also be a variable signal for an increased spirometric response to systemic corticosteroids [125]. Other studies reported that FeNO could be a predictor of increased FEV $_{1}$ by ICS $[104,105,133]$. However, whether FeNO is useful for predicting both symptoms and airflow limitation with ICS treatment in patients with COPD is poorly documented. The findings of our de-stress study demonstrated that, in the several Type2 biomarkers, FeNO was identified as the most accurate predictor for benefits from ICS (AUC $=0.92)$ [88]. Furthermore, the baseline FeNO values were significantly correlated with changes in $\operatorname{FEV}_{1}(\rho=0.835, p<0.0001)$ and CAT $(\rho=-0.672, p<0.0001)$ after treatment with ICS, supporting the usefulness of FeNO as a predictor of ICS responsiveness. 
We proposed two cut-off values for FeNO: $35 \mathrm{ppb}$ is associated with certainty for response inclusion, and $20 \mathrm{ppb}$ is associated with certainty for response exclusion. However, further studies are needed to confirm the usefulness of FeNO for many patients, including current smokers, and determine the appropriate cut-off value. Furthermore, future prospective studies should be focused on detecting biomarkers for predicting the long-term prevention of exacerbations.

\subsection{IgE, Atopy}

\subsubsection{Evaluation of Atopy in Patients with COPD}

Atopy is defined as "a personal, and/or familial tendency, to become sensitized and produce IgE antibodies in response to ordinary exposure to allergens, usually proteins" [134]. There are various measures of atopy, such as positive skin-prick tests and elevated serum IgE levels. Current studies define atopic sensitization as a positive allergen-specific serum IgE (most commonly specific IgE levels $>0.35 \mathrm{kUa} / \mathrm{L}$ ) or a positive skin-prick test (usually, but not exclusively, a wheal diameter $\geq 3 \mathrm{~mm}$ ) to any typical food or inhalant allergen [135]. Atopy has been recognized as a significant contributor to the pathophysiology of asthma. Although atopy has been less well studied in patients with COPD, it has been considered that atopy is a risk indicator of COPD since more than 50 years ago. The Dutch Hypothesis, put forward in 1961, proposes that there are common host factors for asthma and COPD, including atopy and airway hyperresponsiveness [136]. In a longitudinal study, there was a significant inverse association between total serum $\operatorname{IgE}$ and $\mathrm{FEV}_{1} / \mathrm{FVC}$ that was independent of smoking and asthma status [137]. These findings suggest that atopy could potentially influence the impairment of lung growth and decline in lung function over time. From the findings of longitudinal studies, it continues to become clearer that atopy has a potential role in the disease expression or progression of COPD. Therefore, the evaluation of atopy for the management of COPD may become important in the future.

The reported positive rate of atopy in COPD varies between about 15-40\% [57,112,138-145]. Jamieson et al. found a prevalence of $29 \%$ with atopy in a population of 77 former smokers with COPD in the CODE cohort. They found that COPD patients with allergic sensitization had increased respiratory symptoms and exacerbation rates [142]. Fattahi et al. demonstrated the atopic status in the EUROSCOP [141]. It was also evaluated for the incidence and remission of respiratory symptoms of patients during a 3-year follow-up and for the association of atopy with the decline of lung function. This study found that atopy, defined as a positive specific IgE, was present in $18 \%$ of the 1277 current smoking COPD patients. It was found that, compared with nonatopic COPD patients, atopic COPD patients were more likely male, younger, and obese. Moreover, the presence of atopy was associated with increased cough and chest tightness, but not with a decline of $\mathrm{FEV}_{1}$. In contrast, other studies showed an association with the sensitization to Aspergillus antigens and pulmonary function. Bafadhel et al. determined that atopy (defined by a positive skin prick test and/or elevated allergen-specific antibodies) was present in $34 \%$ of 128 COPD patients [140]. Especially, sensitization to Aspergillus fumigatus was shown to be $13 \%$, which was associated with severe airflow limitation. Jin et al. reported that the prevalence of elevated total-IgE and sensitization to Aspergillus fumigatus was $47 \%$ and $15 \%$, respectively [139]. In this study, total serum IgE levels were found to be negatively correlated with $\mathrm{FEV}_{1} \%$ predicted. Given the multiple links between Aspergillus species and bronchiectasis [146], sensitization to Aspergillus antigens may play an important role in the development of COPD-related bronchiectasis. In fact, a recent report found a high prevalence of Aspergillus fumigatus sensitization in COPD patients (18\%), which highlights a potential role for sensitization to Aspergillus fumigatus in COPD-related bronchiectasis [138].

\subsubsection{Atopy as a Biomarker of ICS Treatment Response in COPD}

There has been a growing interest in finding the link between atopy and responses to ICS therapy in COPD patients. However, only a few studies evaluated whether IgE/atopy can predict the response 
when adding corticosteroids in COPD patients. In the EUROSCOP, compared to non-atopic COPD patients, those with atopy more often showed remission of respiratory symptoms when treated with ICS [141]. However, there was no significant difference in changes in post-bronchodilator FEV $_{1}$ between atopic and non-atopic patients who received ICS. Akamatsu et al. examined the possibility of whether atopy predicts the ICS/LABA treatment response in COPD patients. The patients with atopy (defined by positive specific IgE) showed significantly higher improvement in $\mathrm{FEV}_{1}$ [147], and atopy yielded $60 \%$ sensitivity and $89 \%$ specificity for an improvement in $\mathrm{FEV}_{1}$. The findings of our de-stress study were in line with previous studies. Atopy was useful for predicting improvements in both symptoms and airflow limitation with ICS treatment [88]. AUC for atopy was 0.79 , and the sensitivity and specificity yielded $75 \%$ and $84 \%$, respectively.

\subsection{Composite Biomarkers}

In recent years, the diversity of airway inflammation and the development of biologics for asthma have led to increased attention given to evaluations of the composite Type 2 biomarkers. Some researchers have suggested the importance of suppressing both persistent eosinophilia and high FeNO for the management of asthma control $[50,148]$. Recently, the diversity of airway inflammation in COPD has also attracted attention. Based on the findings that the correlations between FeNO values and blood eosinophil counts in patients with severe and extremely severe COPD were not significant, Chen et al. have proposed that FeNO and blood eosinophil counts should be both evaluated in patients with COPD [113]. The use of composite Type2 biomarkers has been recommended for the definition and diagnosis of ACO in several national and international guidelines $[149,150]$. In fact, several studies showed that the combination of blood eosinophil counts and FeNO was useful in differentiating asthma from COPD or ACO from COPD [151,152].

Additionally, in clinical practice, it could be more important for predicting the therapeutic effect of ICS to evaluate the composite Type2 biomarkers. Akamatsu et al. reported that combining FeNO and specific IgE may be a surrogate marker for predicting the response to ICS/LABA on airflow limitation in patients with COPD [147]. For these reasons, we predict that evaluating the composite Type2 biomarkers in COPD patients will become increasingly important. Thus, we focused on the prevalence of Type2 inflammation features of 167 ICS-naïve COPD patients using a combination of multiple Type2 biomarkers available for daily clinical practice. In this study, COPD outpatients were retrospectively enrolled in two tertiary care facilities in Japan from April 2017 to March 2020. Patients with current diagnosis of asthma and current smokers were excluded. The Type 2 inflammation features were determined by the presence of atopy (positive specific IgE for any inhaled antigen) and/or elevated FeNO ( $\geq 35 \mathrm{ppb}$ ), and/or blood eosinophilia ( $\geq 300$ cells $/ \mu \mathrm{L}$ ). Since the Japanese Respiratory Society guidelines recommend that $35 \mathrm{ppb}$ as a reference value to capture the inflammatory condition characteristic of asthma, we have set the reference value for FeNO at $35 \mathrm{ppb}[153,154]$. A Venn diagram and the positive prevalence of Type2 inflammation features are shown in Figure 1. Twenty-three percent of subjects had atopy, $18 \%$ of those had elevated FeNO, and $16 \%$ of those had blood eosinophilia. By combing Type 2 biomarkers, more than $40 \%$ of the patients were positive for at least one Type 2 biomarker, and $13 \%$ of the patients had multiple biomarkers. Furthermore, patients with multiple positive biomarkers showed a trend in higher rates of exacerbation than patients without them. Although the role of the composite Type2 biomarkers in COPD patients remains unclear, the findings of our study will help develop a clinical decision-making strategy for the appropriate use of ICS in COPD patients. 


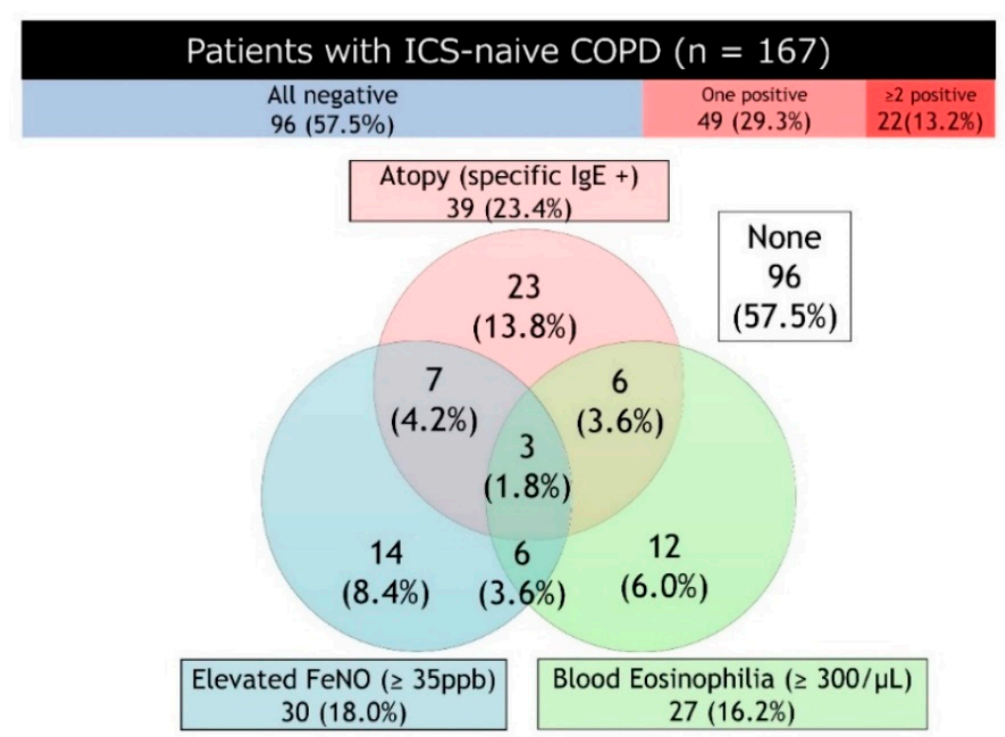

Figure 1. Venn diagram and the positive prevalence of Type 2 inflammation features. Abbreviations: COPD, chronic obstructive pulmonary disease; FeNO, exhaled nitric oxide fraction (FeNO); ICS, inhaled corticosteroid; IgE, Immunoglobulin E.

\section{Emerging Type2 Biomarkers in COPD}

\subsection{Periostin}

Periostin, a matricellular protein produced by airway epithelial cells under the control of IL-4 and IL-13, is a key molecule linking TType2/eosinophilic airway inflammation and remodeling in asthma [155]. Periostin can be detected in the blood and is relatively stable without being affected by ICSs, serving as a marker of the phenotype and a rapid decline of pulmonary function [156]. When interpreting data, attention should be paid to differences in the ELISA kits used. An open-label, single-arm, prospective study in 130 stable COPD patients found that high plasma periostin (Adipo Bioscience kit: $>23 \mathrm{ng} / \mathrm{mL})$ levels were associated with $\mathrm{FEV}_{1}$ responders $(>12 \%$ and $>200 \mathrm{~mL}$ increase in $\mathrm{FEV}_{1}$ from baseline: $43 \%$ of responders versus $24 \%$ of non-responders, $p=0.027$ ) after 12 -week treatment with an ICS/LABA [157]. However, serum periostin alone was not a significant predictor of $\mathrm{FEV}_{1}$ responders. The serum periostin (Human Periostin/OSF-2 DuoSet kit) levels in 155 patients hospitalized for acute exacerbations of COPD were higher on admission compared to discharge (34.7 versus $25.9 \mathrm{ng} / \mathrm{mL}, p=0.003$ ), and frequent exacerbators had higher levels of serum periostin at discharge. However, there were no correlations between the serum periostin levels and severity of airflow obstruction or blood eosinophils on admission [158]. A previous study assessed the effect of smoking on serum periostin by using the Elecsys Periostin immunoassay in COPD patients and healthy controls [159]. COPD smokers and past-smokers had significantly higher periostin levels (51.8 and $54.8 \mathrm{ng} / \mathrm{mL}$, respectively) compared to healthy smokers $(44.6 \mathrm{ng} / \mathrm{mL}$ ), but not healthy never smokers $(49.7 \mathrm{ng} / \mathrm{mL})$. However, the periostin levels did not reflect Type2-driven inflammation, airway remodeling, or ICS treatment responsiveness.

\subsection{Chitinase-3-Like Protein 1 (YKL-40)}

Chitinase-3-like protein 1, also known as YKL-40, is a secreted glycoprotein produced by various cell types, including macrophages, neutrophils, and airway epithelial cells [160]. The multicenter BIOAIR study found that the serum YKL-40 levels were elevated in patients with asthma and COPD (the COPD levels were higher than those in asthma) compared to healthy controls [161]. Negative correlations were observed with lung function, but not with Type2 biomarkers, including FeNO, blood eosinophils, periostin, and IgE. A previous study in severe asthma patients revealed correlations 
between YKL-40 levels and markers associated with neutrophilic airway inflammation [162]. Another study found that serum YKL-40 levels were elevated in healthy smokers and COPD patients compared to healthy never smokers [163]. In sputum, the YKL-40 levels were increased in COPD patients compared to healthy never smokers, suggesting smoking-related activation of airway inflammatory cells. However, no significant differences were observed in the serum and sputum YKL-40 levels between patients with and those without sputum eosinophilia $(>3 \%)$. Thus, it is unlikely that the serum YKL-40 levels reflect Type2/eosinophilic inflammation in COPD.

\subsection{Eosinophil-Derived Neurotoxin (EDN)}

In addition to eosinophil cationic protein and major basic protein, EDN is a granule contained in the matrix of eosinophils [164]. Previous studies indicated that serum EDN is a marker of eosinophilic inflammation [164-166]. One study found a significant negative correlation between the serum EDN levels and lung function $\left(\mathrm{FEV}_{1}\right.$ and $\left.\mathrm{FEV}_{1} / \mathrm{FVC}\right)$ in asthma patients [164]. Another study showed that serum EDN predicted the severe asthma phenotype in a multivariate regression analysis [165]. Recently, serum EDN was found to better reflect the asthma control status than blood eosinophil counts [166]. However, there are no reports assessing serum EDN as a biomarker of Type2/eosinophilic inflammation in COPD.

\subsection{Role of Biomarkers in Identifying Asthma-COPD Overlap (ACO)}

Distinguishing asthma from COPD, and diagnosing ACO as having both features, are important, although there is currently no consensus on its definition. ACO is heterogeneous and includes different phenotypes such as non-Type 2 or non-eosinophilic asthma, and non-emphysematous or frequently exacerbating COPD. However, Type2 biomarkers may be useful in diagnosing ACO derived from COPD because adding an ICS to the treatment regimen is critical for such patients. Previous studies assessed the usefulness of several biomarkers in distinguishing ACO from asthma and COPD [167-169]. Wang et al. found that plasma YKL-40 and neutrophil gelatinase-associated lipocalin (NGAL), but not the periostin, levels, were higher in COPD patients than in patients with asthma or ACO [167]. Pérez de Llano et al. investigated the role of systemic and Type 2 markers and found that serum IL- 5 was lower and IL-8 was higher in COPD patients than in asthma patients [168]. However, there was no difference in these levels between COPD and ACO patients. There was also no difference in serum periostin among the three patient groups. Gon et al. reported that the serum YKL-40 levels were significantly higher in patients with ACO and COPD than in those with asthma, suggesting neutrophilic inflammation in ACO patients [169]. Together, these reports clarified the usefulness of some biomarkers in differentiating between asthma, COPD, and ACO. However, the heterogeneous nature of ACO was not considered, and the possibility of combined assessment of biomarkers was expected.

We assessed the potential roles of serum periostin, YKL-40, and EDN for identifying ACO, and investigated their relevance to other Type2 biomarkers in a cross-sectional study [170,171]. Subjects included patients with asthma $(n=177)$, ACO $(n=115)$, and COPD $(n=61)$ of the ASCOPE cohort (Nihon University Itabashi Hospital and Shizuoka General Hospital). Serum periostin, YKL-40, and EDN were measured using the Elecsys Periostin immunoassay, Human Chitinase 3-like 1 Quantikine ELISA Kit, and MBL EDN ELISA Kit, respectively. Serum periostin was significantly higher in asthma and ACO than in COPD, whereas serum YKL-40 was significantly higher in COPD and ACO than in asthma. Serum EDN was significantly higher in ACO than in asthma or COPD. Based on the cutoff values derived by a ROC analysis (periostin: $55.1 \mathrm{ng} / \mathrm{mL}$; YKL-40: $61.3 \mathrm{ng} / \mathrm{mL}$; and EDN: $23.0 \mathrm{ng} / \mathrm{mL}$ ), patients were classified into high or low groups. The proportion of patients with high serum EDN and YKL-40 levels was significantly higher in ACO than in asthma or COPD: odds ratio, 3.85 (95\% CI, 2.35-6.36); $p<0.001$; sensitivity, 45.2\%; specificity, $82.4 \%$. The AUC of the ROC analysis for detecting ACO was significantly higher in serum EDN plus YKL-40 than in serum periostin plus YKL-40. There was a weak positive correlation between the serum periostin and eosinophil counts, FeNO, total IgE, YKL-40, $\mathrm{FEV}_{1}$, and $\mathrm{FEV}_{1} / \mathrm{FVC}$ in COPD. There was no correlation between serum 
YKL-40 and these parameters. There was a weak or moderate positive correlation between serum EDN and eosinophil counts, FeNO, YKL-40, $\mathrm{FEV}_{1}$, and $\mathrm{FEV}_{1} / \mathrm{FVC}$ in COPD.

One hundred and fifteen patients with ACO consisting of 86 patients derived from asthma, denoted as ACO (asthma), and 29 derived from COPD, denoted as ACO (COPD). Serum biomarkers in these patients are shown in Figure 2. Serum EDN levels were significantly higher in patients with ACO (COPD) than in those with COPD. Possible explanations for the difference between patients with ACO (COPD) and ACO (asthma) included lower FEV 1 /FVC (42.6\% [34.7-61.4] vs. 60.7\% [48.4-66.4], $p<0.001)$ and fewer ICS users (28\% vs. $95 \%, p<0.001)$ in ACO (COPD) patients. However, there was no difference in the serum periostin or YKL-40 levels between patients with ACO (COPD) and those with COPD. The AUC of the ROC analysis for differentiating ACO (COPD) from COPD was significantly higher in serum EDN than in serum periostin or YKL-40, with a cut-off value of $22.4 \mathrm{ng} / \mathrm{mL}$, a sensitivity of $86.2 \%$, a specificity of $55.7 \%$, and an AUC of $0.75(95 \% \mathrm{CI}, 0.64-0.85 ; p=0.002)$ (Figure 3 ). If confirmed in other populations, these findings may facilitate more accurate identification of ACO from COPD, leading to early intervention with ICSs.
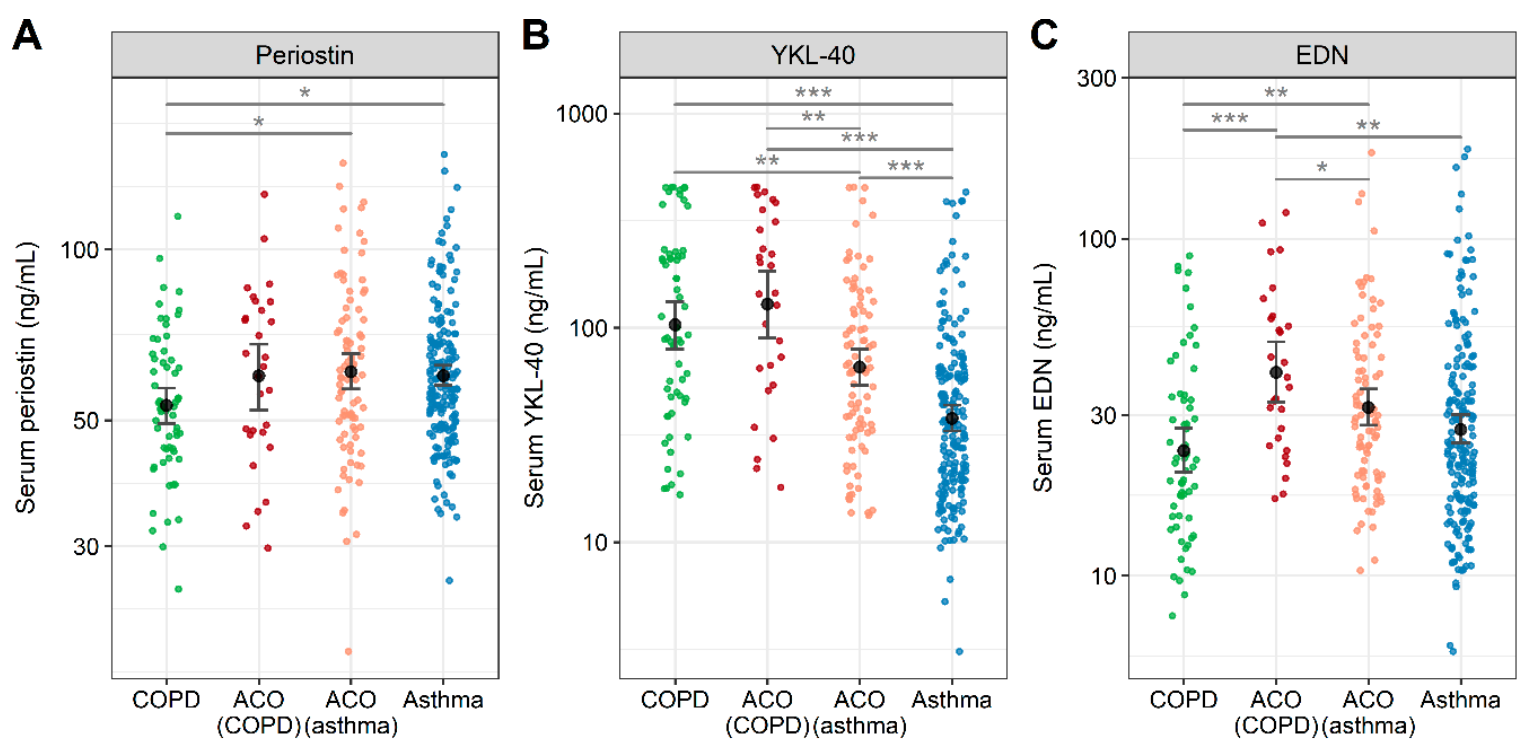

Figure 2. Comparison of serum periostin (A), YKL-40 (B), and EDN (C) among patients with COPD, ACO (COPD), ACO (asthma), and asthma. Abbreviations: ACO, asthma-COPD overlap; COPD, chronic obstructive pulmonary disease; EDN, eosinophil-derived neurotoxin; YKL-40, chitinase-3-like protein $1 .{ }^{*} p<0.05,{ }^{* *} p<0.01,{ }^{* * *} p<0.001$. Reproduced based on the data reported from Ref. [170,171]. 


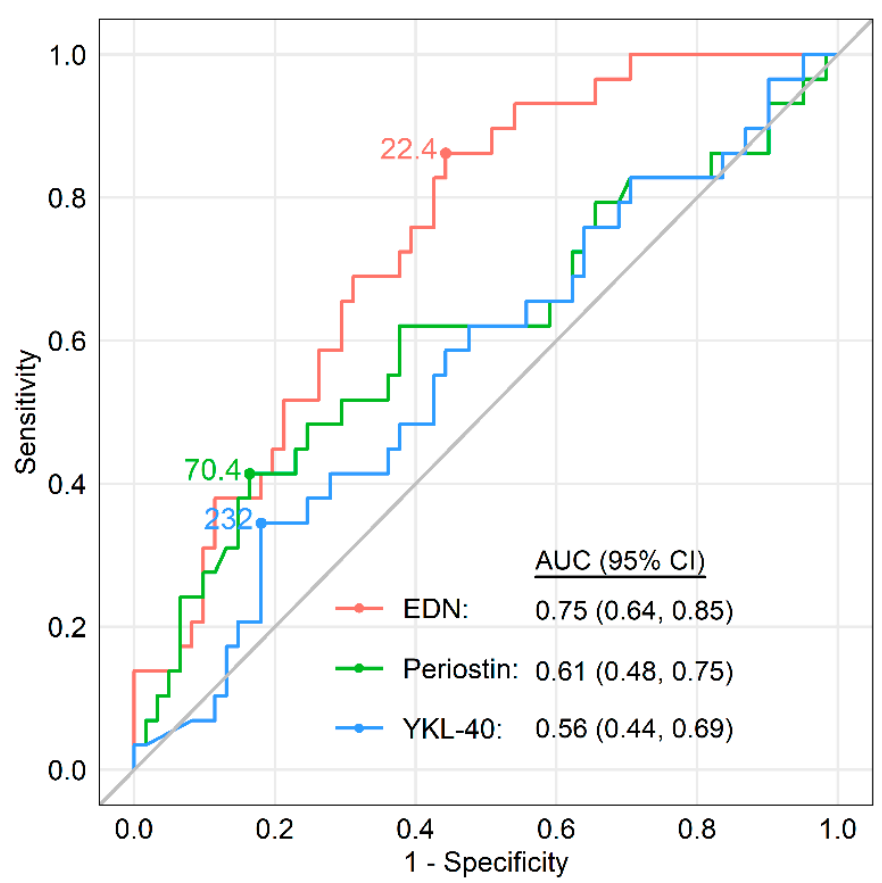

Figure 3. Receiver operating characteristics curves for serum EDN, periostin, and YKL-40 distinguishing ACO (COPD) from COPD with the optimal cut-off values: EDN, $22.4 \mathrm{ng} / \mathrm{mL}$; periostin, $70.4 \mathrm{ng} / \mathrm{mL}$; and YKL-40, $232 \mathrm{ng} / \mathrm{mL}$. Statistical significance is shown for EDN alone. Abbreviations: ACO, asthma-COPD overlap; COPD, chronic obstructive pulmonary disease; EDN, eosinophil-derived neurotoxin; YKL-40, chitinase-3-like protein 1. Reproduced based on the data reported from Ref. [170,171].

\section{Conclusions}

Existent and emerging Type2 biomarkers have been investigated extensively in patients with COPD. Although the evidence about Type2 biomarkers in COPD is inconclusive compared to asthma, Type2 biomarkers have shown some potential when analyzing various clinical outcomes or therapeutic responses to ICS. New clinical trials for ICS treatment and prospective studies for predicting the future risk could enable stratification of COPD patients according to Type2 biomarkers, which might clarify this important issue. In the near future, the examination of Type2 biomarkers will be clearly one of the mainstream tools leading to personalized COPD management.

Author Contributions: K.O., conceptualization, writing-original draft preparation, writing-review and editing; K.M., conceptualization and writing - review and editing; T.S., writing-original draft preparation, writing - review and editing; K.H. and Y.G., writing — review and editing. All authors have read and agreed to the published version of the manuscript.

Funding: This work received no external funding.

Acknowledgments: The authors thank Brent Bell for reading the manuscript.

Conflicts of Interest: Keiji Oishi declares no conflict of interest. Kazuto Matsunaga has received consulting fees and lecture fees from Boehringer Ingelheim, Astellas, Astra-Zeneca, Sanofi, Meiji-Seika pharma, Novartis, Kyorin pharma, Chest, Torii pharma, and GlaxoSmithKline outside the submitted work. Toshihiro Shirai reports personal fees from AstraZeneca Japan, GlaxoSmithKline Japan, Boehringer Ingelheim Japan, and Novartis Pharma outside of the submitted work. Keita Hirai declare no conflict of interest. Yasuhiro Gon reports personal fees from AstraZeneca Japan, GlaxoSmithKline Japan, Boehringer Ingelheim Japan, and Novartis Pharma outside of the submitted work. 


\section{References}

1. Singh, D.; Agusti, A.; Anzueto, A.; Barnes, P.J.; Bourbeau, J.; Celli, B.R.; Criner, G.J.; Frith, P.; Halpin, D.M.; Han, M. Global strategy for the diagnosis, management, and prevention of chronic obstructive lung disease: The GOLD science committee report 2019. Eur. Respir. J. 2019, 53, 1900164. [CrossRef] [PubMed]

2. Barnes, P.J. Inflammatory mechanisms in patients with chronic obstructive pulmonary disease. J. Allergy Clin. Immunol. 2016, 138, 16-27. [CrossRef] [PubMed]

3. Christenson, S.A.; Steiling, K.; van den Berge, M.; Hijazi, K.; Hiemstra, P.S.; Postma, D.S.; Lenburg, M.E.; Spira, A.; Woodruff, P.G. Asthma-COPD overlap. Clinical relevance of genomic signatures of type 2 inflammation in chronic obstructive pulmonary disease. Am. J. Respir. Crit. Care Med. 2015, 191, 758-766. [CrossRef] [PubMed]

4. McGeachie, M.J.; Yates, K.P.; Zhou, X.; Guo, F.; Sternberg, A.L.; Van Natta, M.L.; Wise, R.A.; Szefler, S.J.; Sharma, S.; Kho, A.T.; et al. Patterns of growth and decline in lung function in persistent childhood asthma. N. Engl. J. Med. 2016, 374, 1842-1852. [CrossRef] [PubMed]

5. James, A.L.; Palmer, L.J.; Kicic, E.; Maxwell, P.S.; Lagan, S.E.; Ryan, G.F.; Musk, A.W. Decline in lung function in the Busselton Health Study: The effects of asthma and cigarette smoking. Am. J. Respir. Crit. Care Med. 2005, 171, 109-114. [CrossRef]

6. Strunk, R.C.; Weiss, S.T.; Yates, K.P.; Tonascia, J.; Zeiger, R.S.; Szefler, S.J. Mild to moderate asthma affects lung growth in children and adolescents. J. Allergy Clin. Immunol. 2006, 118, 1040-1047. [CrossRef]

7. Bisgaard, H.; Jensen, S.M.; Bønnelykke, K. Interaction between asthma and lung function growth in early life. Am. J. Respir. Crit. Care Med. 2012, 185, 1183-1189. [CrossRef]

8. Morgan, W.J.; Stern, D.A.; Sherrill, D.L.; Guerra, S.; Holberg, C.J.; Guilbert, T.W.; Taussig, L.M.; Wright, A.L.; Martinez, F.D. Outcome of asthma and wheezing in the first 6 years of life: Follow-up through adolescence. Am. J. Respir. Crit. Care Med. 2005, 172, 1253-1258. [CrossRef]

9. Håland, G.; Carlsen, K.C.; Sandvik, L.; Devulapalli, C.S.; Munthe-Kaas, M.C.; Pettersen, M.; Carlsen, K.H. Reduced lung function at birth and the risk of asthma at 10 years of age. N. Engl. J. Med. 2006, 355, 1682-1689. [CrossRef]

10. Martinez, F.D.; Vercelli, D. Asthma. Lancet 2013, 382, 1360-1372. [CrossRef]

11. Sears, M.R.; Greene, J.M.; Willan, A.R.; Wiecek, E.M.; Taylor, D.R.; Flannery, E.M.; Cowan, J.O.; Herbison, G.P.; Silva, P.A.; Poulton, R. A longitudinal, population-based, cohort study of childhood asthma followed to adulthood. N. Engl. J. Med. 2003, 349, 1414-1422. [CrossRef]

12. Bui, D.S.; Lodge, C.J.; Burgess, J.A.; Lowe, A.J.; Perret, J.; Bui, M.Q.; Bowatte, G.; Gurrin, L.; Johns, D.P.; Thompson, B.R.; et al. Childhood predictors of lung function trajectories and future COPD risk: A prospective cohort study from the first to the sixth decade of life. Lancet Respir. Med. 2018, 6, 535-544. [CrossRef]

13. Hikichi, M.; Mizumura, K.; Maruoka, S.; Gon, Y. Pathogenesis of chronic obstructive pulmonary disease (COPD) induced by cigarette smoke. J. Thorac. Dis. 2019, 11, S2129-S2140. [CrossRef] [PubMed]

14. Global Initiative for Chronic Obstructive Lung Disease (GOLD). Global Strategy for the Diagnosis Management, and Prevention of Chronic Obstructive Pulmonary Disease (2020 REPORT). Available online: https:/goldcopd.org/gold-reports/ (accessed on 1 May 2020).

15. Yun, J.H.; Lamb, A.; Chase, R.; Singh, D.; Parker, M.M.; Saferali, A.; Vestbo, J.; Tal-Singer, R.; Castaldi, P.J.; Silverman, E.K.; et al. Blood eosinophil count thresholds and exacerbations in patients with chronic obstructive pulmonary disease. J. Allergy Clin. Immunol. 2018, 141, 2037-2047.e2010. [CrossRef] [PubMed]

16. Singh, D.; Kolsum, U.; Brightling, C.E.; Locantore, N.; Agusti, A.; Tal-Singer, R.; ECLIPSE Investigators. Eosinophilic inflammation in COPD: Prevalence and clinical characteristics. Eur. Respir. J. 2014, 44, 1697-1700. [CrossRef]

17. George, L.; Brightling, C.E. Eosinophilic airway inflammation: Role in asthma and chronic obstructive pulmonary disease. Ther. Adv. Chron. Dis. 2016, 7, 34-51. [CrossRef]

18. Brusselle, G.G.; Maes, T.; Bracke, K.R. Eosinophils in the spotlight: Eosinophilic airway inflammation in nonallergic asthma. Nat. Med. 2013, 19, 977-979. [CrossRef]

19. De Grove, K.C.; Provoost, S.; Verhamme, F.M.; Bracke, K.R.; Joos, G.F.; Maes, T.; Brusselle, G.G. Characterization and quantification of innate lymphoid cell subsets in human lung. PLoS ONE 2016, 11, e0145961. [CrossRef] 
20. Scanlon, S.T.; McKenzie, A.N. Type 2 innate lymphoid cells: New players in asthma and allergy. Curr. Opin. Immunol. 2012, 24, 707-712. [CrossRef]

21. Byers, D.E.; Alexander-Brett, J.; Patel, A.C.; Agapov, E.; Dang-Vu, G.; Jin, X.; Wu, K.; You, Y.; Alevy, Y.; Girard, J.P.; et al. Long-term IL-33-producing epithelial progenitor cells in chronic obstructive lung disease. J. Clin. Investig. 2013, 123, 3967-3982. [CrossRef]

22. Wu, H.; Yang, S.; Wu, X.; Zhao, J.; Zhao, J.; Ning, Q.; Xu, Y.; Xie, J. Interleukin-33/ST2 signaling promotes production of interleukin- 6 and interleukin-8 in systemic inflammation in cigarette smoke-induced chronic obstructive pulmonary disease mice. Biochem. Biophys. Res. Commun. 2014, 450, 110-116. [CrossRef] [PubMed]

23. Qiu, C.; Li, Y.; Li, M.; Li, M.; Liu, X.; McSharry, C.; Xu, D. Anti-interleukin-33 inhibits cigarette smoke-induced lung inflammation in mice. Immunology 2013, 138, 76-82. [CrossRef] [PubMed]

24. Nakamura, Y.; Miyata, M.; Ohba, T.; Ando, T.; Hatsushika, K.; Suenaga, F.; Shimokawa, N.; Ohnuma, Y.; Katoh, R.; Ogawa, H.; et al. Cigarette smoke extract induces thymic stromal lymphopoietin expression, leading to $\mathrm{T}(\mathrm{H}) 2$-type immune responses and airway inflammation. J. Allergy Clin. Immunol. 2008, 122, 1208-1214. [CrossRef] [PubMed]

25. Ying, S.; O'Connor, B.; Ratoff, J.; Meng, Q.; Fang, C.; Cousins, D.; Zhang, G.; Gu, S.; Gao, Z.; Shamji, B.; et al. Expression and cellular provenance of thymic stromal lymphopoietin and chemokines in patients with severe asthma and chronic obstructive pulmonary disease. J. Immunol. 2008, 181, 2790-2798. [CrossRef] [PubMed]

26. Zhang, K.; Shan, L.; Rahman, M.S.; Unruh, H.; Halayko, A.J.; Gounni, A.S. Constitutive and inducible thymic stromal lymphopoietin expression in human airway smooth muscle cells: Role in chronic obstructive pulmonary disease. Am. J. Physiol. Lung Cell Mol. Physiol. 2007, 293, L375-L382. [CrossRef]

27. Kim, S.W.; Rhee, C.K.; Kim, K.U.; Lee, S.H.; Hwang, H.G.; Kim, Y.I.; Kim, D.K.; Lee, S.D.; Oh, Y.M.; Yoon, H.K. Factors associated with plasma IL-33 levels in patients with chronic obstructive pulmonary disease. Int. J. Chron. Obstruct. Pulmon. Dis. 2017, 12, 395-402. [CrossRef]

28. Sun, B.B.; Ma, L.J.; Qi, Y.; Zhang, G.J. Correlation of IL-33 gene polymorphism with chronic obstructive pulmonary disease. Eur. Rev. Med. Pharmacol. Sci. 2019, 23, 6277-6282.

29. Xia, J.; Zhao, J.; Shang, J.; Li, M.; Zeng, Z.; Zhao, J.; Wang, J.; Xu, Y.; Xie, J. Increased IL-33 expression in chronic obstructive pulmonary disease. Am. J. Physiol. Lung Cell Mol. Physiol. 2015, 308, L619-L627. [CrossRef]

30. Tworek, D.; Majewski, S.; Szewczyk, K.; Kiszalkiewicz, J.; Kurmanowska, Z.; Gorski, P.; Brzezianska-Lasota, E.; Kuna, P.; Antczak, A. The association between airway eosinophilic inflammation and IL-33 in stable non-atopic COPD. Respir. Res. 2018, 19, 108. [CrossRef]

31. Papi, A.; Bellettato, C.M.; Braccioni, F.; Romagnoli, M.; Casolari, P.; Caramori, G.; Fabbri, L.M.; Johnston, S.L. Infections and airway inflammation in chronic obstructive pulmonary disease severe exacerbations. Am. J. Respir. Crit. Care Med. 2006, 173, 1114-1121. [CrossRef]

32. Bafadhel, M.; McKenna, S.; Terry, S.; Mistry, V.; Reid, C.; Haldar, P.; McCormick, M.; Haldar, K.; Kebadze, T.; Duvoix, A.; et al. Acute exacerbations of chronic obstructive pulmonary disease: Identification of biologic clusters and their biomarkers. Am. J. Respir. Crit. Care Med. 2011, 184, 662-671. [CrossRef] [PubMed]

33. Fujimoto, K.; Yasuo, M.; Urushibata, K.; Hanaoka, M.; Koizumi, T.; Kubo, K. Airway inflammation during stable and acutely exacerbated chronic obstructive pulmonary disease. Eur. Respir. J. 2005, 25, 640-646. [CrossRef] [PubMed]

34. Saetta, M.; Di Stefano, A.; Maestrelli, P.; Turato, G.; Ruggieri, M.P.; Roggeri, A.; Calcagni, P.; Mapp, C.E.; Ciaccia, A.; Fabbri, L.M. Airway eosinophilia in chronic bronchitis during exacerbations. Am. J. Respir. Crit. Care Med. 1994, 150, 1646-1652. [CrossRef] [PubMed]

35. Schumann, D.M.; Tamm, M.; Kostikas, K.; Stolz, D. Stability of the blood eosinophilic phenotype in stable and exacerbated COPD. Chest 2019, 156, 456-465. [CrossRef]

36. Kolsum, U.; Donaldson, G.C.; Singh, R.; Barker, B.L.; Gupta, V.; George, L.; Webb, A.J.; Thurston, S.; Brookes, A.J.; McHugh, T.D.; et al. Blood and sputum eosinophils in COPD; relationship with bacterial load. Respir. Res. 2017, 18, 88. [CrossRef]

37. Orie, N. The Host Factor in Bronchitis; Charles C Thomas: Springfield, IL, USA, 1961. 
38. Eltboli, O.; Bafadhel, M.; Hollins, F.; Wright, A.; Hargadon, B.; Kulkarni, N.; Brightling, C. COPD exacerbation severity and frequency is associated with impaired macrophage efferocytosis of eosinophils. BMC Pulm. Med. 2014, 14, 112. [CrossRef]

39. Leigh, R.; Pizzichini, M.M.; Morris, M.M.; Maltais, F.; Hargreave, F.E.; Pizzichini, E. Stable COPD: Predicting benefit from high-dose inhaled corticosteroid treatment. Eur. Respir. J. 2006, 27, 964-971. [CrossRef]

40. Pizzichini, E.; Pizzichini, M.M.; Gibson, P.; Parameswaran, K.; Gleich, G.J.; Berman, L.; Dolovich, J.; Hargreave, F.E. Sputum eosinophilia predicts benefit from prednisone in smokers with chronic obstructive bronchitis. Am. J. Respir. Crit.Care Med. 1998, 158, 1511-1517. [CrossRef]

41. Brightling, C.E.; McKenna, S.; Hargadon, B.; Birring, S.; Green, R.; Siva, R.; Berry, M.; Parker, D.; Monteiro, W.; Pavord, I.D.; et al. Sputum eosinophilia and the short term response to inhaled mometasone in chronic obstructive pulmonary disease. Thorax 2005, 60, 193-198. [CrossRef]

42. Siva, R.; Green, R.H.; Brightling, C.E.; Shelley, M.; Hargadon, B.; McKenna, S.; Monteiro, W.; Berry, M.; Parker, D.; Wardlaw, A.J.; et al. Eosinophilic airway inflammation and exacerbations of COPD: A randomised controlled trial. Eur. Respir. J. 2007, 29, 906-913. [CrossRef]

43. Brightling, C.E.; Monteiro, W.; Ward, R.; Parker, D.; Morgan, M.D.; Wardlaw, A.J.; Pavord, I.D. Sputum eosinophilia and short-term response to prednisolone in chronic obstructive pulmonary disease: A randomised controlled trial. Lancet 2000, 356, 1480-1485. [CrossRef]

44. Hastie, A.T.; Martinez, F.J.; Curtis, J.L.; Doerschuk, C.M.; Hansel, N.N.; Christenson, S.; Putcha, N.; Ortega, V.E.; Li, X.; Barr, R.G.; et al. Association of sputum and blood eosinophil concentrations with clinical measures of COPD severity: An analysis of the SPIROMICS cohort. Lancet Respir. Med. 2017, 5, $956-967$. [CrossRef]

45. Bakakos, A.; Loukides, S.; Bakakos, P. Severe eosinophilic asthma. J. Clin. Med. 2019, 8, 1375. [CrossRef] [PubMed]

46. Anderson, W.C., 3rd; Apter, A.J.; Dutmer, C.M.; Searing, D.A.; Szefler, S.J. Advances in asthma in 2016: Designing individualized approaches to management. J. Allergy Clin. Immunol. 2017, 140, 671-680. [CrossRef]

47. Chung, K.F. Precision medicine in asthma: Linking phenotypes to targeted treatments. Curr. Opin. Pulm. Med. 2018, 24, 4-10. [CrossRef]

48. Yancey, S.W.; Keene, O.N.; Albers, F.C.; Ortega, H.; Bates, S.; Bleecker, E.R.; Pavord, I. Biomarkers for severe eosinophilic asthma. J. Allergy Clin. Immunol. 2017, 140, 1509-1518. [CrossRef]

49. Pignatti, P.; Visca, D.; Cherubino, F.; Zampogna, E.; Lucini, E.; Saderi, L.; Sotgiu, G.; Spanevello, A. Do blood eosinophils strictly reflect airway inflammation in COPD? Comparison with asthmatic patients. Respir. Res. 2019, 20, 145. [CrossRef]

50. Malinovschi, A.; Janson, C.; Borres, M.; Alving, K. Simultaneously increased fraction of exhaled nitric oxide levels and blood eosinophil counts relate to increased asthma morbidity. J. Allergy Clin. Immunol. 2016, 138, 1301-1308.e1302. [CrossRef]

51. Rabe, K.F.; Watz, H.; Baraldo, S.; Pedersen, F.; Biondini, D.; Bagul, N.; Hanauer, G.; Göhring, U.M.; Purkayastha, D.; Román, J.; et al. Anti-inflammatory effects of roflumilast in chronic obstructive pulmonary disease (ROBERT): A 16-week, randomised, placebo-controlled trial. Lancet Respir. Med. 2018, 6, 827-836. [CrossRef]

52. Eltboli, O.; Mistry, V.; Barker, B.; Brightling, C.E. Relationship between blood and bronchial submucosal eosinophilia and reticular basement membrane thickening in chronic obstructive pulmonary disease. Respirology 2015, 20, 667-670. [CrossRef]

53. Kolsum, U.; Damera, G.; Pham, T.H.; Southworth, T.; Mason, S.; Karur, P.; Newbold, P.; Singh, D. Pulmonary inflammation in patients with chronic obstructive pulmonary disease with higher blood eosinophil counts. J. Allergy Clin. Immunol. 2017, 140, 1181-1184.e1187. [CrossRef] [PubMed]

54. Turato, G.; Semenzato, U.; Bazzan, E.; Biondini, D.; Tinè, M.; Torrecilla, N.; Forner, M.; Marin, J.M.; Cosio, M.G.; Saetta, M. Blood eosinophilia neither reflects tissue eosinophils nor worsens clinical outcomes in chronic obstructive pulmonary disease. Am. J. Respir. Crit. Care Med. 2018, 197, 1216-1219. [CrossRef] [PubMed]

55. Vedel-Krogh, S.; Nielsen, S.F.; Lange, P.; Vestbo, J.; Nordestgaard, B.G. Blood eosinophils and exacerbations in chronic obstructive pulmonary disease. The Copenhagen general population study. Am. J. Respir. Crit. Care Med. 2016, 193, 965-974. [CrossRef] [PubMed]

56. Watz, H.; Tetzlaff, K.; Wouters, E.F.; Kirsten, A.; Magnussen, H.; Rodriguez-Roisin, R.; Vogelmeier, C.; Fabbri, L.M.; Chanez, P.; Dahl, R.; et al. Blood eosinophil count and exacerbations in severe chronic 
obstructive pulmonary disease after withdrawal of inhaled corticosteroids: A post-hoc analysis of the WISDOM trial. Lancet Respir. Med. 2016, 4, 390-398. [CrossRef]

57. Suzuki, M.; Makita, H.; Konno, S.; Shimizu, K.; Kimura, H.; Kimura, H.; Nishimura, M. Asthma-like features and clinical course of chronic obstructive pulmonary disease. An analysis from the Hokkaido COPD cohort study. Am. J. Respir. Crit. Care Med. 2016, 194, 1358-1365. [CrossRef]

58. Oshagbemi, O.A.; Burden, A.M.; Braeken, D.C.W.; Henskens, Y.; Wouters, E.F.M.; Driessen, J.H.M.; Maitland-van der Zee, A.H.; de Vries, F.; Franssen, F.M.E. Stability of blood eosinophils in patients with chronic obstructive pulmonary disease and in control subjects, and the impact of sex, age, smoking, and baseline counts. Am. J. Respir. Crit. Care Med. 2017, 195, 1402-1404. [CrossRef]

59. Casanova, C.; Celli, B.R.; de-Torres, J.P.; Martínez-Gonzalez, C.; Cosio, B.G.; Pinto-Plata, V.; de Lucas-Ramos, P.; Divo, M.; Fuster, A.; Peces-Barba, G.; et al. Prevalence of persistent blood eosinophilia: Relation to outcomes in patients with COPD. Eur. Respir. J. 2017, 50, 1701162. [CrossRef]

60. Kovalszki, A.; Weller, P.F. Eosinophilia. Prim. Care. 2016, 43, 607-617. [CrossRef]

61. Schleich, F.; Corhay, J.L.; Louis, R. Blood eosinophil count to predict bronchial eosinophilic inflammation in COPD. Eur. Respir. J. 2016, 47, 1562-1564. [CrossRef]

62. Zeiger, R.S.; Schatz, M.; Li, Q.; Chen, W.; Khatry, D.B.; Gossage, D.; Tran, T.N. High blood eosinophil count is a risk factor for future asthma exacerbations in adult persistent asthma. J. Allergy Clin. Immunol. Pract. 2014, 2,741-750. [CrossRef]

63. Zeiger, R.S.; Tran, T.N.; Butler, R.K.; Schatz, M.; Li, Q.; Khatry, D.B.; Martin, U.; Kawatkar, A.A.; Chen, W. Relationship of blood eosinophil count to exacerbations in chronic obstructive pulmonary disease. J. Allergy Clin. Immunol. Pract. 2018, 6, 944-954.e945. [CrossRef] [PubMed]

64. Adir, Y.; Hakrush, O.; Shteinberg, M.; Schneer, S.; Agusti, A. Circulating eosinophil levels do not predict severe exacerbations in COPD: A retrospective study. ERJ Open Res. 2018, 4, 00022-2018. [CrossRef] [PubMed]

65. Zysman, M.; Deslee, G.; Caillaud, D.; Chanez, P.; Escamilla, R.; Court-Fortune, I.; Nesme-Meyer, P.; Perez, T.; Paillasseur, J.L.; Pinet, C.; et al. Relationship between blood eosinophils, clinical characteristics, and mortality in patients with COPD. Int. J. Chron. Obstruct. Pulmon. Dis. 2017, 12, 1819-1824. [CrossRef] [PubMed]

66. Kerkhof, M.; Sonnappa, S.; Postma, D.S.; Brusselle, G.; Agustí, A.; Anzueto, A.; Jones, R.; Papi, A.; Pavord, I.; Pizzichini, E.; et al. Blood eosinophil count and exacerbation risk in patients with COPD. Eur. Respir. J. 2017, 50, 1700761. [CrossRef] [PubMed]

67. Shin, S.H.; Park, H.Y.; Kang, D.; Cho, J.; Kwon, S.O.; Park, J.H.; Lee, J.S.; Oh, Y.M.; Sin, D.D.; Kim, W.J.; et al. Serial blood eosinophils and clinical outcome in patients with chronic obstructive pulmonary disease. Respir. Res. 2018, 19, 134. [CrossRef] [PubMed]

68. Hancox, R.J.; Pavord, I.D.; Sears, M.R. Associations between blood eosinophils and decline in lung function among adults with and without asthma. Eur. Respir. J. 2018, 51, 1702536. [CrossRef]

69. Nishimura, M.; Makita, H.; Nagai, K.; Konno, S.; Nasuhara, Y.; Hasegawa, M.; Shimizu, K.; Betsuyaku, T.; Ito, Y.M.; Fuke, S.; et al. Annual change in pulmonary function and clinical phenotype in chronic obstructive pulmonary disease. Am. J. Respir. Crit. Care Med. 2012, 185, 44-52. [CrossRef]

70. Suzuki, M.; Makita, H.; Konno, S.; Shimizu, K.; Nasuhara, Y.; Nagai, K.; Akiyama, Y.; Fuke, S.; Saito, H.; Igarashi, T.; et al. Annual change in FEV(1) in elderly 10-year survivors with established chronic obstructive pulmonary disease. Sci. Rep. 2019, 9, 2073. [CrossRef]

71. Price, D.B.; Voorham, J.; Brusselle, G.; Clemens, A.; Kostikas, K.; Stephens, J.W.; Park, H.Y.; Roche, N.; Fogel, R. Inhaled corticosteroids in COPD and onset of type 2 diabetes and osteoporosis: Matched cohort study. NPJ Prim. Care Respir. Med. 2019, 29, 38. [CrossRef]

72. Ernst, P.; Saad, N.; Suissa, S. Inhaled corticosteroids in COPD: The clinical evidence. Eur.Respir. J. 2015, 45, 525-537. [CrossRef]

73. Pascoe, S.; Barnes, N.; Brusselle, G.; Compton, C.; Criner, G.J.; Dransfield, M.T.; Halpin, D.M.G.; Han, M.K.; Hartley, B.; Lange, P.; et al. Blood eosinophils and treatment response with triple and dual combination therapy in chronic obstructive pulmonary disease: Analysis of the IMPACT trial. Lancet Respir. Med. 2019, 7, 745-756. [CrossRef]

74. Ferguson, G.T.; Rabe, K.F.; Martinez, F.J.; Fabbri, L.M.; Wang, C.; Ichinose, M.; Bourne, E.; Ballal, S.; Darken, P.; DeAngelis, K.; et al. Triple therapy with budesonide/glycopyrrolate/formoterol fumarate with co-suspension delivery technology versus dual therapies in chronic obstructive pulmonary disease 
(KRONOS): A double-blind, parallel-group, multicentre, phase 3 randomised controlled trial. Lancet Respir. Med. 2018, 6, 747-758. [PubMed]

75. Barnes, N.C.; Sharma, R.; Lettis, S.; Calverley, P.M. Blood eosinophils as a marker of response to inhaled corticosteroids in COPD. Eur. Respir. J. 2016, 47, 1374-1382. [CrossRef] [PubMed]

76. Vestbo, J.; Papi, A.; Corradi, M.; Blazhko, V.; Montagna, I.; Francisco, C.; Cohuet, G.; Vezzoli, S.; Scuri, M.; Singh, D. Single inhaler extrafine triple therapy versus long-acting muscarinic antagonist therapy for chronic obstructive pulmonary disease (TRINITY): A double-blind, parallel group, randomised controlled trial. Lancet. 2017, 389, 1919-1929. [CrossRef]

77. Pascoe, S.; Locantore, N.; Dransfield, M.T.; Barnes, N.C.; Pavord, I.D. Blood eosinophil counts, exacerbations, and response to the addition of inhaled fluticasone furoate to vilanterol in patients with chronic obstructive pulmonary disease: A secondary analysis of data from two parallel randomised controlled trials. Lancet Respir. Med. 2015, 3, 435-442. [CrossRef]

78. Papi, A.; Vestbo, J.; Fabbri, L.; Corradi, M.; Prunier, H.; Cohuet, G.; Guasconi, A.; Montagna, I.; Vezzoli, S.; Petruzzelli, S.; et al. Extrafine inhaled triple therapy versus dual bronchodilator therapy in chronic obstructive pulmonary disease (TRIBUTE): A double-blind, parallel group, randomised controlled trial. Lancet 2018, 391, 1076-1084. [CrossRef]

79. Siddiqui, S.H.; Guasconi, A.; Vestbo, J.; Jones, P.; Agusti, A.; Paggiaro, P.; Wedzicha, J.A.; Singh, D. Blood eosinophils: A biomarker of response to extrafine beclomethasone/Formoterol in chronic obstructive pulmonary disease. Am. J. Respir. Crit. Care Med. 2015, 192, 523-525. [CrossRef] [PubMed]

80. Bafadhel, M.; Peterson, S.; De Blas, M.A.; Calverley, P.M.; Rennard, S.I.; Richter, K.; Fagerås, M. Predictors of exacerbation risk and response to budesonide in patients with chronic obstructive pulmonary disease: A post-hoc analysis of three randomised trials. Lancet Respir. Med. 2018, 6, 117-126. [CrossRef]

81. Lipson, D.A.; Barnhart, F.; Brealey, N.; Brooks, J.; Criner, G.J.; Day, N.C.; Dransfield, M.T.; Halpin, D.M.G.; Han, M.K.; Jones, C.E.; et al. Once-Daily Single-Inhaler Triple versus Dual Therapy in Patients with COPD. N. Engl. J. Med. 2018, 378, 1671-1680. [CrossRef]

82. Chapman, K.R.; Hurst, J.R.; Frent, S.M.; Larbig, M.; Fogel, R.; Guerin, T.; Banerji, D.; Patalano, F.; Goyal, P.; Pfister, P.; et al. Long-term triple therapy DE-escalation to indacaterol/Glycopyrronium in patients with chronic obstructive pulmonary disease (Sunset): A randomized, double-blind, triple-dummy clinical trial. Am. J. Respir. Crit. Care Med. 2018, 198, 329-339. [CrossRef]

83. Song, J.H.; Lee, C.H.; Kim, J.W.; Lee, W.Y.; Jung, J.Y.; Park, J.H.; Jung, K.S.; Yoo, K.H.; Park, Y.B.; Kim, D.K. Clinical implications of blood eosinophil count in patients with non-asthma-COPD overlap syndrome COPD. Int. J. Chron. Obstruct. Pulmon. Dis. 2017, 12, 2455-2464. [CrossRef] [PubMed]

84. Oshagbemi, O.A.; Franssen, F.M.E.; Braeken, D.C.W.; Henskens, Y.; Wouters, E.F.M.; Maitland-van der Zee, A.H.; Burden, A.M.; de Vries, F. Blood eosinophilia, use of inhaled corticosteroids, and risk of COPD exacerbations and mortality. Pharmacoepidemiol. Drug Saf. 2018, 27, 1191-1199. [CrossRef] [PubMed]

85. Herland, K.; Akselsen, J.P.; Skjønsberg, O.H.; Bjermer, L. How representative are clinical study patients with asthma or COPD for a larger "real life" population of patients with obstructive lung disease? Respir. Med. 2005, 99, 11-19. [CrossRef] [PubMed]

86. Oishi, K.; Hirano, T.; Hamada, K.; Uehara, S.; Suetake, R.; Yamaji, Y.; Ito, K.; Asami-Noyama, M.; Edakuni, N.; Matsunaga, K. Characteristics of 2017 GOLD COPD group A: A multicenter cross-sectional CAP study in Japan. Int. J. Chron. Obstruct. Pulmon. Dis. 2018, 13, 3901-3907. [CrossRef] [PubMed]

87. Cabrera López, C.; Casanova Macario, C.; Marín Trigo, J.M.; de-Torres, J.P.; Sicilia Torres, R.; González, J.M.; Polverino, F.; Divo, M.; Pinto Plata, V.; Zulueta, J.J.; et al. Comparison of the 2017 and 2015 global initiative for chronic obstructive lung disease reports. Impact on grouping and outcomes. Am. J. Respir. Crit. Care Med. 2018, 197, 463-469. [CrossRef] [PubMed]

88. Yamaji, Y.; Oishi, K.; Hamada, K.; Ohteru, Y.; Chikumoto, A.; Murakawa, K.; Matsuda, K.; Suetake, R.; Murata, Y.; Ito, K.; et al. Detection of type2 biomarkers for response in COPD. J. Breath Res. 2020, 14, 026007. [CrossRef]

89. Smith, A.D.; Cowan, J.O.; Brassett, K.P.; Herbison, G.P.; Taylor, D.R. Use of exhaled nitric oxide measurements to guide treatment in chronic asthma. N. Engl. J. Med. 2005, 352, 2163-2173. [CrossRef]

90. Dweik, R.A.; Boggs, P.B.; Erzurum, S.C.; Irvin, C.G.; Leigh, M.W.; Lundberg, J.O.; Olin, A.C.; Plummer, A.L.; Taylor, D.R.; American Thoracic Society Committee on Interpretation of Exhaled Nitric Oxide Levels for 
Clinical. An official ATS clinical practice guideline: Interpretation of exhaled nitric oxide levels (FENO) for clinical applications. Am. J. Respir. Crit. Care Med. 2011, 184, 602-615. [CrossRef]

91. Tee, K.H.; Hui, K.P. Clips, spirometry, and submaximal inhalation for exhaled nitric oxide. Am. J. Respir. Crit. Care Med. 2005, 172, 931-932. [CrossRef]

92. Global Initiative for Asthma. 2020 GINA Report, Global Strategy for Asthma Management and Prevention, Updated 2020. Available online: http://ginasthma.org (accessed on 20 April 2020).

93. Alving, K.; Malinovschi, A. Basic aspects of exhaled nitric oxide. Eur. Respir. Soc. Monograph. 2010, 49, 1-31.

94. Castro, M.; Corren, J.; Pavord, I.D.; Maspero, J.; Wenzel, S.; Rabe, K.F.; Busse, W.W.; Ford, L.; Sher, L.; FitzGerald, J.M.; et al. Dupilumab Efficacy and Safety in Moderate-to-Severe Uncontrolled Asthma. N. Engl. J. Med. 2018, 378, 2486-2496. [CrossRef]

95. Rabe, K.F.; Nair, P.; Brusselle, G.; Maspero, J.F.; Castro, M.; Sher, L.; Zhu, H.; Hamilton, J.D.; Swanson, B.N.; Khan, A.; et al. Efficacy and safety of dupilumab in glucocorticoid-dependent severe asthma. N. Engl. J. Med. 2018, 378, 2475-2485. [CrossRef] [PubMed]

96. Maestrelli, P.; Páska, C.; Saetta, M.; Turato, G.; Nowicki, Y.; Monti, S.; Formichi, B.; Miniati, M.; Fabbri, L.M. Decreased haem oxygenase-1 and increased inducible nitric oxide synthase in the lung of severe COPD patients. Eur. Respir. J. 2003, 21, 971-976. [CrossRef] [PubMed]

97. Jiang, W.T.; Liu, X.S.; Xu, Y.J.; Ni, W.; Chen, S.X. Expression of nitric oxide synthase isoenzyme in lung tissue of smokers with and without chronic obstructive pulmonary disease. Chin. Med. J. (Engl.) 2015, 128, 1584-1589. [CrossRef] [PubMed]

98. Corradi, M.; Mutti, A. Nitric oxide synthase isoforms in lung parenchyma of patients with chronic obstructive pulmonary disease. Am. J. Respir. Crit. Care Med. 2010, 181, 3-4. [CrossRef]

99. Lu, Z.; Huang, W.; Wang, L.; Xu, N.; Ding, Q.; Cao, C. Exhaled nitric oxide in patients with chronic obstructive pulmonary disease: A systematic review and meta-analysis. Int. J. Chron. Obstruct. Pulmon. Dis. 2018, 13, 2695-2705. [CrossRef]

100. Michils, A.; Louis, R.; Peché, R.; Baldassarre, S.; Van Muylem, A. Exhaled nitric oxide as a marker of asthma control in smoking patients. Eur. Respir. J. 2009, 33, 1295-1301. [CrossRef]

101. Matsunaga, K.; Hirano, T.; Akamatsu, K.; Koarai, A.; Sugiura, H.; Minakata, Y.; Ichinose, M. Exhaled nitric oxide cutoff values for asthma diagnosis according to rhinitis and smoking status in Japanese subjects. Allergol. Int. 2011, 60, 331-337. [CrossRef]

102. Olin, A.C.; Rosengren, A.; Thelle, D.S.; Lissner, L.; Bake, B.; Torén, K. Height, age, and atopy are associated with fraction of exhaled nitric oxide in a large adult general population sample. Chest 2006, 130, 1319-1325. [CrossRef]

103. Kharitonov, S.A.; Yates, D.H.; Barnes, P.J. Inhaled glucocorticoids decrease nitric oxide in exhaled air of asthmatic patients. Am. J. Respir. Crit. Care Med. 1996, 153, 454-457. [CrossRef]

104. Kunisaki, K.M.; Rice, K.L.; Janoff, E.N.; Rector, T.S.; Niewoehner, D.E. Exhaled nitric oxide, systemic inflammation, and the spirometric response to inhaled fluticasone propionate in severe chronic obstructive pulmonary disease: A prospective study. Ther. Adv. Respir. Dis. 2008, 2, 55-64. [CrossRef] [PubMed]

105. Feng, J.X.; Lin, Y.; Lin, J.; He, S.S.; Chen, M.F.; Wu, X.M.; Xu, Y.Z. Relationship between Fractional Exhaled Nitric Oxide Level and Efficacy of Inhaled Corticosteroid in Asthma-COPD Overlap Syndrome Patients with Different Disease Severity. J. Korean Med. Sci. 2017, 32, 439-447. [CrossRef] [PubMed]

106. Goto, T.; Camargo, C.A., Jr.; Hasegawa, K. Fractional exhaled nitric oxide levels in asthma-COPD overlap syndrome: Analysis of the National Health and Nutrition Examination Survey, 2007-2012. Int. J. Chron Obstruct. Pulmon. Dis. 2016, 11, 2149-2155. [CrossRef]

107. Cosío, B.G.; Pérez de Llano, L.; Lopez Viña, A.; Torrego, A.; Lopez-Campos, J.L.; Soriano, J.B.; Martinez Moragon, E.; Izquierdo, J.L.; Bobolea, I.; Callejas, J.; et al. Th-2 signature in chronic airway diseases: Towards the extinction of asthma-COPD overlap syndrome? Eur. Respir. J. 2017, 49, 1602397. [CrossRef] [PubMed]

108. Deng, D.D.; Zhou, A.Y.; Shuang, Q.C.; Chen, P. The value of fractionated exhaled nitric oxide in the diagnosis of asthma-chronic obstructive pulmonary disease overlap syndrome. Zhonghua Jie He He Hu Xi Za Zhi 2017, 40, 98-101. [PubMed]

109. Kobayashi, S.; Hanagama, M.; Yamanda, S.; Ishida, M.; Yanai, M. Inflammatory biomarkers in asthma-COPD overlap syndrome. Int. J. Chron. Obstruct. Pulmon. Dis. 2016, 11, 2117-2123. [CrossRef] [PubMed] 
110. Chen, F.J.; Huang, X.Y.; Liu, Y.L.; Lin, G.P.; Xie, C.M. Importance of fractional exhaled nitric oxide in the differentiation of asthma-COPD overlap syndrome, asthma, and COPD. Int. J. Chron. Obstruct. Pulmon. Dis. 2016, 11, 2385-2390.

111. Alcázar-Navarrete, B.; Romero-Palacios, P.J.; Ruiz-Sancho, A.; Ruiz-Rodriguez, O. Diagnostic performance of the measurement of nitric oxide in exhaled air in the diagnosis of COPD phenotypes. Nitric Oxide 2016, 54, 67-72. [CrossRef]

112. Tamada, T.; Sugiura, H.; Takahashi, T.; Matsunaga, K.; Kimura, K.; Katsumata, U.; Takekoshi, D.; Kikuchi, T.; Ohta, K.; Ichinose, M. Biomarker-based detection of asthma-COPD overlap syndrome in COPD populations. Int. J. Chron. Obstruct. Pulmon. Dis. 2015, 10, 2169-2176. [CrossRef]

113. Chen, F.J.; Lin, G.P.; Huang, X.Y.; Liu, Y.L.; Zeng, Z.M.; Guo, Y.B. Evaluation of the characteristics of asthma in severe and extremely severe COPD. Int. J. Chron. Obstruct. Pulmon. Dis. 2019, 14, 2663-2671. [CrossRef]

114. Bhowmik, A.; Seemungal, T.A.; Donaldson, G.C.; Wedzicha, J.A. Effects of exacerbations and seasonality on exhaled nitric oxide in COPD. Eur. Respir. J. 2005, 26, 1009-1015. [CrossRef] [PubMed]

115. Antus, B.; Barta, I.; Horvath, I.; Csiszer, E. Relationship between exhaled nitric oxide and treatment response in COPD patients with exacerbations. Respirology 2010, 15, 472-477. [CrossRef] [PubMed]

116. Agustí, A.G.; Villaverde, J.M.; Togores, B.; Bosch, M. Serial measurements of exhaled nitric oxide during exacerbations of chronic obstructive pulmonary disease. Eur. Respir. J. 1999, 14, 523-528. [CrossRef] [PubMed]

117. Lázár, Z.; Kelemen, Á.; Gálffy, G.; Losonczy, G.; Horváth, I.; Bikov, A. Central and peripheral airway nitric oxide in patients with stable and exacerbated chronic obstructive pulmonary disease. J. Breath Res. 2018, 12, 036017. [CrossRef]

118. Xia, Q.; Pan, P.; Wang, Z.; Lu, R.; Hu, C. Fractional exhaled nitric oxide in bronchial inflammatory lung diseases. Zhong Nan Da Xue Xue Bao Yi Xue Ban 2014, 39, 365-370.

119. Sanders, S.P.; Proud, D.; Permutt, S.; Siekierski, E.S.; Yachechko, R.; Liu, M.C. Role of nasal nitric oxide in the resolution of experimental rhinovirus infection. J. Allergy Clin. Immunol. 2004, 113, 697-702. [CrossRef]

120. Viniol, C.; Vogelmeier, C.F. Exacerbations of COPD. Eur. Respir. Rev. 2018, 27, 170103. [CrossRef]

121. Alcázar-Navarrete, B.; Ruiz Rodríguez, O.; Conde Baena, P.; Romero Palacios, P.J.; Agusti, A. Persistently elevated exhaled nitric oxide fraction is associated with increased risk of exacerbation in COPD. Eur. Respir. J. 2018, 51, 1701457. [CrossRef]

122. Dweik, R.A.; Sorkness, R.L.; Wenzel, S.; Hammel, J.; Curran-Everett, D.; Comhair, S.A.; Bleecker, E.; Busse, W.; Calhoun, W.J.; Castro, M.; et al. Use of exhaled nitric oxide measurement to identify a reactive, at-risk phenotype among patients with asthma. Am. J. Respir. Crit. Care Med. 2010, 181, 1033-1041. [CrossRef]

123. Matsunaga, K.; Hirano, T.; Oka, A.; Ito, K.; Edakuni, N. Persistently high exhaled nitric oxide and loss of lung function in controlled asthma. Allergol. Int. 2016, 65, 266-271. [CrossRef]

124. Matsunaga, K.; Katoh, N.; Fujieda, S.; Izuhara, K.; Oishi, K. Dupilumab: Basic aspects and applications to allergic diseases. Allergol. Int. 2020, 69, 187-196. [CrossRef] [PubMed]

125. Dummer, J.F.; Epton, M.J.; Cowan, J.O.; Cook, J.M.; Condliffe, R.; Landhuis, C.E.; Smith, A.D.; Taylor, D.R. Predicting corticosteroid response in chronic obstructive pulmonary disease using exhaled nitric oxide. Am. J. Respir. Crit. Care Med. 2009, 180, 846-852. [CrossRef] [PubMed]

126. De Laurentiis, G.; Maniscalco, M.; Cianciulli, F.; Stanziola, A.; Marsico, S.; Lundberg, J.O.; Weitzberg, E.; Sofia, M. Exhaled nitric oxide monitoring in COPD using a portable analyzer. Pulm. Pharmacol. Ther. 2008, 21, 689-693. [CrossRef] [PubMed]

127. Lehouck, A.; Carremans, C.; De Bent, K.; Decramer, M.; Janssens, W. Alveolar and bronchial exhaled nitric oxide in chronic obstructive pulmonary disease. Respir. Med. 2010, 104, 1020-1026. [CrossRef]

128. Beg, M.F.; Alzoghaibi, M.A.; Abba, A.A.; Habib, S.S. Exhaled nitric oxide in stable chronic obstructive pulmonary disease. Ann. Thorac Med. 2009, 4, 65-70.

129. Ansarin, K.; Chatkin, J.M.; Ferreira, I.M.; Gutierrez, C.A.; Zamel, N.; Chapman, K.R. Exhaled nitric oxide in chronic obstructive pulmonary disease: Relationship to pulmonary function. Eur. Respir. J. 2001, 17, 934-938. [CrossRef]

130. Liu, X.; Zhang, H.; Wang, Y.; Lu, Y.; Gao, Y.; Lu, Y.; Zheng, C.; Yin, D.; Wang, S.; Huang, K. Fractional exhaled nitric oxide is associated with the severity of stable COPD. COPD 2020, 17, 121-127. [CrossRef]

131. Lim, C.S.; Rani, F.A.; Tan, L.E. Response of exhaled nitric oxide to inhaled corticosteroids in patients with stable COPD: A systematic review and meta-analysis. Clin. Respir. J. 2018, 12, 218-226. [CrossRef] 
132. Clini, E.; Cremona, G.; Campana, M.; Scotti, C.; Pagani, M.; Bianchi, L.; Giordano, A.; Ambrosino, N. Production of endogenous nitric oxide in chronic obstructive pulmonary disease and patients with cor pulmonale. Correlates with echo-Doppler assessment. Am. J. Respir. Crit. Care Med. 2000, 162, 446-450. [CrossRef]

133. Zietkowski, Z.; Kucharewicz, I.; Bodzenta-Lukaszyk, A. The influence of inhaled corticosteroids on exhaled nitric oxide in stable chronic obstructive pulmonary disease. Respir. Med. 2005, 99, 816-824. [CrossRef]

134. Johansson, S.G.O.; Haahtela, T.; World Allergy Organization. Prevention of Allergy and Allergic Asthma: World Allergy Organization Project Report and Guidelines; Karger Medical and Scientific Publishers: Basel, Switzerland, 2004.

135. O'Hehir, R.E.; Holgate, S.T.; Sheikh, A. Middleton's Allergy Essentials E-Book; Elsevier Health Sciences: Amsterdam, The Netherlands, 2015.

136. Sluiter, H.J.; Koëter, G.H.; de Monchy, J.G.; Postma, D.S.; de Vries, K.; Orie, N.G. The Dutch hypothesis (chronic non-specific lung disease) revisited. Eur. Respir. J. 1991, 4, 479-489. [PubMed]

137. Sherrill, D.L.; Lebowitz, M.D.; Halonen, M.; Barbee, R.A.; Burrows, B. Longitudinal evaluation of the association between pulmonary function and total serum IgE. Am. J. Respir. Crit. Care Med. 1995, 152, 98-102. [CrossRef]

138. Everaerts, S.; Lagrou, K.; Dubbeldam, A.; Lorent, N.; Vermeersch, K.; Van Hoeyveld, E.; Bossuyt, X.; Dupont, L.J.; Vanaudenaerde, B.M.; Janssens, W. Sensitization to Aspergillus fumigatus as a risk factor for bronchiectasis in COPD. Int. J. Chron. Obstruct. Pulmon. Dis. 2017, 12, 2629-2638. [CrossRef] [PubMed]

139. Jin, J.; Liu, X.; Sun, Y. The prevalence of increased serum IgE and Aspergillus sensitization in patients with COPD and their association with symptoms and lung function. Respir. Res. 2014, 15, 130. [CrossRef] [PubMed]

140. Bafadhel, M.; McKenna, S.; Agbetile, J.; Fairs, A.; Desai, D.; Mistry, V.; Morley, J.P.; Pancholi, M.; Pavord, I.D.; Wardlaw, A.J.; et al. Aspergillus fumigatus during stable state and exacerbations of COPD. Eur. Respir. J. 2014, 43, 64-71. [CrossRef]

141. Fattahi, F.; ten Hacken, N.H.; Löfdahl, C.G.; Hylkema, M.N.; Timens, W.; Postma, D.S.; Vonk, J.M. Atopy is a risk factor for Respir.atory symptoms in COPD patients: Results from the EUROSCOP study. Respir. Res. 2013, 14, 10. [CrossRef]

142. Jamieson, D.B.; Matsui, E.C.; Belli, A.; McCormack, M.C.; Peng, E.; Pierre-Louis, S.; Curtin-Brosnan, J.; Breysse, P.N.; Diette, G.B.; Hansel, N.N. Effects of allergic phenotype on Respir.atory symptoms and exacerbations in patients with chronic obstructive pulmonary disease. Am. J. Respir. Crit. Care Med. 2013, 188, 187-192. [CrossRef]

143. Bożek, A.; Rogala, B. IgE-dependent sensitization in patients with COPD. Ann. Agric. Environ. Med. 2018, 25, 417-420. [CrossRef]

144. Hu, H.; Huang, H.; Zheng, P.; Li, L.; Cai, C.; Li, N.; Sun, B. The sensitization characteristics of adult Chinese patients diagnosed with chronic respiratory diseases. Asian Pac. J. Allergy Immunol. 2019.

145. Neves, M.C.; Neves, Y.C.; Mendes, C.M.; Bastos, M.N.; Camelier, A.A.; Queiroz, C.F.; Mendoza, B.F.; Lemos, A.C.; D'Oliveira, A., Jr. Evaluation of atopy in patients with COPD. J. Bras. Pneumol. 2013, 39, 296-305. [CrossRef]

146. De Soyza, A.; Aliberti, S. Bronchiectasis and Aspergillus: How are they linked? Med. Mycol. 2017, 55, 69-81. [CrossRef] [PubMed]

147. Akamatsu, K.; Matsunaga, K.; Sugiura, H.; Koarai, A.; Hirano, T.; Minakata, Y.; Ichinose, M. Improvement of airflow limitation by fluticasone propionate/Salmeterol in chronic obstructive pulmonary disease: What is the specific marker? Front. Pharmacol. 2011, 2, 36. [CrossRef] [PubMed]

148. Oishi, K.; Hirano, T.; Suetake, R.; Ohata, S.; Yamaji, Y.; Ito, K.; Edakuni, N.; Matsunaga, K. A trial of oral corticosteroids for persistent systemic and airway inflammation in severe asthma. Immun. Inflamm. Dis. 2017, 5, 261-264. [CrossRef] [PubMed]

149. Yanagisawa, S.; Ichinose, M. Definition and diagnosis of asthma-COPD overlap (ACO). Allergol. Int. 2018, 67, 172-178. [CrossRef]

150. Sin, D.D.; Miravitlles, M.; Mannino, D.M.; Soriano, J.B.; Price, D.; Celli, B.R.; Leung, J.M.; Nakano, Y.; Park, H.Y.; Wark, P.A.; et al. What is asthma-COPD overlap syndrome? Towards a consensus definition from a round table discussion. Eur. Respir. J. 2016, 48, 664-673. [CrossRef] [PubMed] 
151. Takayama, Y.; Ohnishi, H.; Ogasawara, F.; Oyama, K.; Kubota, T.; Yokoyama, A. Clinical utility of fractional exhaled nitric oxide and blood eosinophils counts in the diagnosis of asthma-COPD overlap. Int. J. Chron. Obstruct. Pulmon. Dis. 2018, 13, 2525-2532. [CrossRef]

152. Çolak, Y.; Afzal, S.; Nordestgaard, B.G.; Marott, J.L.; Lange, P. Combined value of exhaled nitric oxide and blood eosinophils in chronic airway disease: The Copenhagen general population study. Eur. Respir. J. 2018, 52, 1800616. [CrossRef]

153. Matsunaga, K.; Hirano, T.; Kawayama, T.; Tsuburai, T.; Nagase, H.; Aizawa, H.; Akiyama, K.; Ohta, K.; Ichinose, M. Reference ranges for exhaled nitric oxide fraction in healthy Japanese adult population. Allergol. Int. 2010, 59, 363-367. [CrossRef]

154. Matsunaga, K.; Kuwahira, I.; Hanaoka, M.; Saito, J.; Tsuburai, T.; Fukunaga, K.; Matsumoto, H.; Sugiura, H.; Ichinose, M. An official JRS statement: The principles of fractional exhaled nitric oxide (FeNO) measurement and interpretation of the results in clinical practice. Respir. Investig. 2020. [CrossRef]

155. Matsumoto, H. Role of serum periostin in the management of asthma and its comorbidities. Respir. Investig. 2020, 58, 144-154. [CrossRef]

156. Kanemitsu, Y.; Matsumoto, H.; Izuhara, K.; Tohda, Y.; Kita, H.; Horiguchi, T.; Kuwabara, K.; Tomii, K.; Otsuka, K.; Fujimura, M.; et al. Increased periostin associates with greater airflow limitation in patients receiving inhaled corticosteroids. J. Allergy Clin. Immunol. 2013, 132, 305-312.e303. [CrossRef]

157. Park, H.Y.; Lee, H.; Koh, W.J.; Kim, S.; Jeong, I.; Koo, H.K.; Kim, T.H.; Kim, J.W.; Kim, W.J.; Oh, Y.M.; et al. Association of blood eosinophils and plasma periostin with FEV1 response after 3-month inhaled corticosteroid and long-acting beta2-agonist treatment in stable COPD patients. Int. J. Chron. Obstruct. Pulmon. Dis. 2016, 11, 23-30. [CrossRef] [PubMed]

158. Konstantelou, E.; Papaioannou, A.I.; Loukides, S.; Bartziokas, K.; Papaporfyriou, A.; Papatheodorou, G.; Bakakos, P.; Papiris, S.; Koulouris, N.; Kostikas, K. Serum periostin in patients hospitalized for COPD exacerbations. Cytokine 2017, 93, 51-56. [CrossRef] [PubMed]

159. Carpaij, O.A.; Muntinghe, F.O.W.; Wagenaar, M.B.; Habing, J.W.; Timens, W.; Kerstjens, H.A.M.; Nawijn, M.C.; Kunz, L.I.Z.; Hiemstra, P.S.; Tew, G.W.; et al. Serum periostin does not reflect type 2-driven inflammation in COPD. Respir. Res. 2018, 19, 112. [CrossRef] [PubMed]

160. Tong, X.; Wang, D.; Liu, S.; Ma, Y.; Li, Z.; Tian, P.; Fan, H. The YKL-40 protein is a potential biomarker for COPD: A meta-analysis and systematic review. Int. J. Chron. Obstruct. Pulmon. Dis. 2018, 13, 409-418. [CrossRef]

161. James, A.J.; Reinius, L.E.; Verhoek, M.; Gomes, A.; Kupczyk, M.; Hammar, U.; Ono, J.; Ohta, S.; Izuhara, K.; Bel, E.; et al. Increased ykl-40 and chitotriosidase in asthma and chronic obstructive pulmonary disease. Am. J. Respir. Crit. Care Med. 2016, 193, 131-142. [CrossRef]

162. Hinks, T.S.C.; Brown, T.; Lau, L.C.K.; Rupani, H.; Barber, C.; Elliott, S.; Ward, J.A.; Ono, J.; Ohta, S.; Izuhara, K.; et al. Multidimensional endotyping in patients with severe asthma reveals inflammatory heterogeneity in matrix metalloproteinases and chitinase 3-like protein 1. J. Allergy Clin. Immunol. 2016, 138, 61-75. [CrossRef]

163. Majewski, S.; Tworek, D.; Szewczyk, K.; Kiszałkiewicz, J.; Kurmanowska, Z.; Brzeziańska-Lasota, E.; Jerczyńska, H.; Antczak, A.; Piotrowski, W.J.; Górski, P. Overexpression of chitotriosidase and YKL-40 in peripheral blood and sputum of healthy smokers and patients with chronic obstructive pulmonary disease. Int. J. Chron. Obstruct. Pulmon. Dis. 2019, 14, 1611-1631. [CrossRef]

164. Gon, Y.; Ito, R.; Hattori, T.; Hiranuma, H.; Kumasawa, F.; Kozu, Y.; Endo, D.; Koyama, D.; Shintani, Y.; Eriko, T.; et al. Serum eosinophil-derived neurotoxin: Correlation with persistent airflow limitation in adults with house-dust mite allergic asthma. Allergy Asthma Proc. 2015, 36, e113-e120. [CrossRef]

165. Lee, Y.; Lee, J.H.; Yang, E.M.; Kwon, E.; Jung, C.G.; Kim, S.C.; Choi, Y.; Cho, Y.S.; Kim, C.K.; Park, H.S. Serum levels of eosinophil-derived neurotoxin: A biomarker for asthma severity in adult asthmatics. Allergy Asthma Immunol. Res. 2019, 11, 394-405. [CrossRef]

166. An, J.; Lee, J.H.; Sim, J.H.; Song, W.J.; Kwon, H.S.; Cho, Y.S.; Moon, H.B.; Kim, C.K.; Kim, T.B. Serum Eosinophil-derived neurotoxin better reflect asthma control status than blood eosinophil counts. J. Allergy Clin. Immunol. Pract. 2020. [CrossRef] [PubMed]

167. Wang, J.; Lv, H.; Luo, Z.; Mou, S.; Liu, J.; Liu, C.; Deng, S.; Jiang, Y.; Lin, J.; Wu, C.; et al. Plasma YKL-40 and NGAL are useful in distinguishing ACO from asthma and COPD. Respir. Res. 2018, 19, 47. [CrossRef] [PubMed] 
168. de Llano, L.P.; Cosío, B.G.; Iglesias, A.; de Las Cuevas, N.; Soler-Cataluña, J.J.; Izquierdo, J.L.; López-Campos, J.L.; Calero, C.; Plaza, V.; Miravitlles, M.; et al. Mixed Th2 and non-Th2 inflammatory pattern in the asthma-COPD overlap: A network approach. Int. J. Chron. Obstruct. Pulmon. Dis. 2018, 13, 591-601. [CrossRef] [PubMed]

169. Gon, Y.; Maruoka, S.; Ito, R.; Mizumura, K.; Kozu, Y.; Hiranuma, H.; Hattori, T.; Takahashi, M.; Hikichi, M.; Hashimoto, S. Utility of serum YKL-40 levels for identification of patients with asthma and COPD. Allergol. Int. 2017, 66, 624-626. [CrossRef]

170. Shirai, T.; Hirai, K.; Gon, Y.; Maruoka, S.; Mizumura, K.; Hikichi, M.; Holweg, C.; Itoh, K.; Inoue, H.; Hashimoto, S. Combined assessment of serum periostin and ykl-40 may identify asthma-COPD overlap. J. Allergy Clin. Immunol. Pract. 2019, 7, 134-145.e131. [CrossRef]

171. Shirai, T.; Hirai, K.; Gon, Y.; Maruoka, S.; Mizumura, K.; Hikichi, M.; Itoh, K.; Hashimoto, S. Combined assessment of serum eosinophil-derived neurotoxin and ykl-40 may identify asthma-COPD overlap. Allergol. Int. 2020, S1323-S8930, 30070. [CrossRef]

(C) 2020 by the authors. Licensee MDPI, Basel, Switzerland. This article is an open access article distributed under the terms and conditions of the Creative Commons Attribution (CC BY) license (http://creativecommons.org/licenses/by/4.0/). 